\title{
Assessment of the Tayabas Bay Fisheries
}

\author{
Maribeth H. Ramos ${ }^{1, \star}$, Esmeralda M. Mendoza1, Wilfredo O. Fajardo Jr. ${ }^{1}$, Fe Lavapie-Gonzales ${ }^{2}$ \\ ${ }^{1}$ Bureau of Fisheries and Aquatic Resources Regional Office 4A, 2nd Floor ICC Building, \\ NIA Compound, EDSA, Diliman, Quezon City 1101, Metro Manila, Philippines \\ ${ }^{2}$ National Fisheries Research and Development Institute, 101 Mother Ignacia Avenue, Quezon City 1103, \\ Metro Manila, Philippines
}

\section{A B S T R A C T}

This technical paper discusses the results of the 10-year assessment (January 2004 to December 2013) of the fisheries of Tayabas Bay to determine the current status and level of exploitation and measure the effects of interventions introduced and implemented in the Bay and adjacent waters of Quezon and Batangas provinces. The trend of catch, effort and catch per unit effort from 2004 to 2013 showed an increase in catch attained by increasing effort, with fluctuating CPUE. The highest catch (24,622.9 MT) was attained in 2012. In 2013 the total production was 22,595.8 MT, an increase of $6.9 \%$ from the 2004 production. The fisherman's density of $20 / \mathrm{km}$ for Tayabas Bay is low compared to other major fishing grounds like Lingayen Gulf, Guimaras Strait, and Manila Bay, but slightly higher than the estimates for Honda Bay and Ormoc Bay. The number of observed boat landings of all gears ranged from 13,746 MT in 2013 to 33,842 MT in 2005. The standardized annual estimated effort of the bottom set gillnet ranged from 2,199,589 MT to 7,194,394 MT. Most of the artisanal or municipal gears such as multiple hook and line ( $7 \mathrm{~kg}$ to $6 \mathrm{~kg}$ ), drift gillnet (53 kg to $7 \mathrm{~kg}$ ), and hook and line ( $9 \mathrm{~kg}$ to $5 \mathrm{~kg}$ ) showed declining catch rates (CPUE). The bottom set gillnet, spear gun and surface gillnet, however, showed an increasing trend. Out of 16 species of fish analyzed, Cypselurus naresii, Rastrelliger faughni, Rastrelliger kanagurta, Decapterus tabl, Siganus canaliculatus and Upeneus sulphureus exhibited an E value exceeding 0.5 , which indicates overexploitation. As to the recruitment, nine species showed bimodal recruitment while seven species showed unimodal recruitment. There are seven species that have a mean length greater than their length at first maturity, which indicates that they have contributed to the recruitment process of their stocks before they are caught.

*E-mail:mhramos59@yahoo.com;nsap4a@yahoo.com

Keywords: Tayabas Bay,

Received: 26 May 2017

Accepted: 5 October 2017

\section{I N T R O D U C T I O N}

$\mathbf{F}$ or the purposes of this study, Tayabas Bay is defined as an area of ocean bounded on the north, northeast, and east by Southern Quezon, in the island of Luzon and demarcated at the south by two imaginary lines going eastward from 121'28'2 E, 13' 41" $44 \mathrm{~N}$ to 122 '03" 17 E, 13' 00" $09 \mathrm{~N}$ (Figure 1).

Tayabas Bay, which forms a rough square with sides of about $60 \mathrm{~km}$ in southern Luzon, has $49 \%$ of its coastline in Quezon Province, $45 \%$ in Marinduque, and $6 \%$ in Batangas.

Studies done in the late 1980s indicated that most of the traditional fishing grounds of the country have reached the overexploited status that is, characterized by the declining trend of total production, change in catch composition and decreased catches. The situation consequently called for an urgency in prioritizing a management program for the fishery sector. It was in this context that the Fishery Sector Program (FSP) was conceptualized and developed. The core of the program was Coastal Resource Management (CRM), one component of which was the establishment of baseline data on the resources on which a management

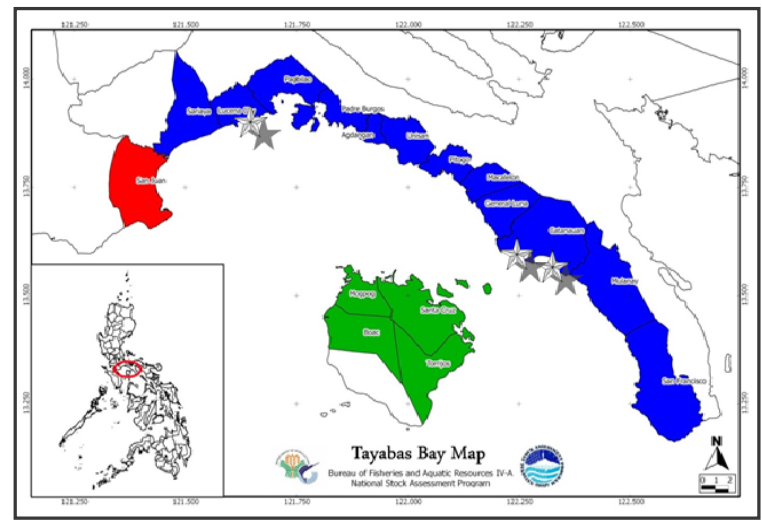

Figure 1. Map of Tayabas Bay showing the location of fish landing areas established as sampling sites for this study.

plan should be based. It focused on 12 overexploited bays, each representing a region; Tayabas Bay was identified as an FSP priority bay for Region 4. One of the main objectives of the program was to strengthen the management capability of the Local Government Units (LGUs) and fisherfolk. 
Table 1. Percentage contribution of the major fishing grounds to the national fishery production in 1980 .

\begin{tabular}{cc}
\hline Fishing Ground & Contribution (\%) \\
\hline Visayan Sea & 18 \\
Moro Gulf & 12 \\
West Sulu Sea & 10 \\
South Sulu Sea & 9 \\
Lamon Bay & 7 \\
East Sulu Sea & 6 \\
Samar Sea & 5 \\
Bohol Sea & 4 \\
Leyte Gulf & 3 \\
Tayabas Bay & 3 \\
\hline
\end{tabular}

Source: BFAR Fishery Statistics, 1978-1987.

Implementation was carried out in 1990 with the following activities: conduct of Resource and Ecological Assessments and Socio-Economic Profiles, mangrove reforestation, installation of artificial reefs, declaration/ establishment of sanctuaries, and enforcement of existing laws.

So as to strengthen further this national concern for fishery resource management and to make available the needed information, Republic Act (RA) 8550, otherwise known as the Philippine Fisheries Code of 1998, particularly Sections 7, 8, and 9, provided that stock assessment studies should be done in order to obtain information for use in the estimation of status of the resource in relation to the management intervention made. The information obtained from the catch monitoring activities may give increasing trends which could inspire fishermen to support and participate in sustaining higher catches. After all, fish resources are renewable resources; they may have reached the state of depletion, but given a serious integrated concern to revive that economic catch level, recovery of depleted fisheries is not far-fetched. Prescription of catch ceiling limitations, establishment of closed seasons, establishment of marine protected areas, and other management measures may be accepted, agreed, and implemented in a coordinated manner.

Likewise, Articles 6 and 7 of the Food and Agriculture Organization (FAO) Code of Conduct for Responsible Fisheries provide that it is then imperative that fish stock assessment study be conducted to provide advice on the optimum exploitation of aquatic living resources in a particular area or fishing ground to assure, in the long run, the self-sustainability of the stock under exploitation (Hilborn and Walters 1992). Some of the conventional biological reference points for fisheries management have been the estimation of sustainable harvest levels such as maximum sustainable yield (MSY), and/or sustainable exploitation rates such as the optimum fishing mortality, fishing effort, and the size of fish to be caught. Assessment studies would likewise

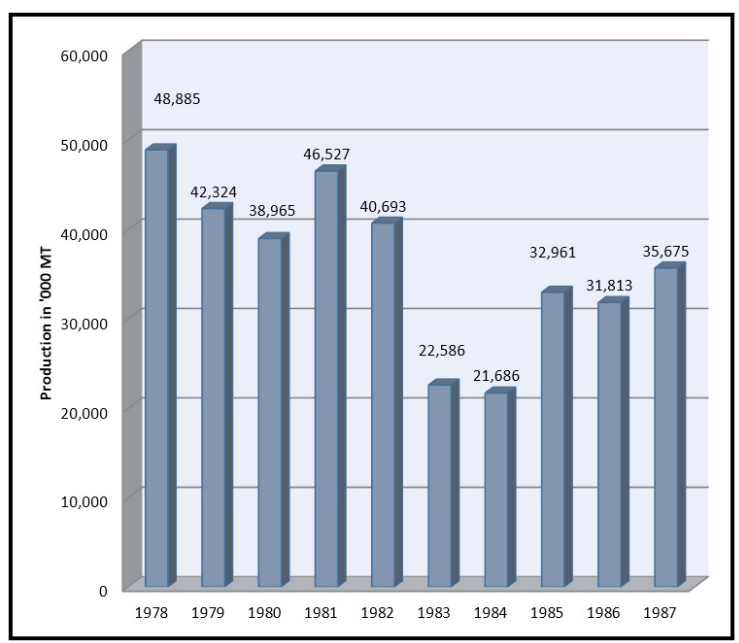

Figure 2. Total fishery production (MT) of Tayabas Bay, 1978-1987.

measure the effects of various interventions introduced and implemented in the study area.

\section{The Study Area}

Tayabas Bay is one of the traditional fishing grounds of the country; it contributed about three percent to the total national production in 1980. Improved production statistics for 9 years (1978-1987), recorded some 48,885 MT in 1978 which declined to less than half in 1983 and 1984 but regained to 35,675 MT in 1987 (Table 1).

The Bay covers 16 municipalities and one city in three provinces, namely: Quezon, Marinduque, and Batangas. In Quezon Province, Lucena City is the lone city along Tayabas Bay; the 11 municipalities are Agdangan, Catanauan, General Luna, Macalelon, Mulanay, Padre Burgos, Pagbilao, Pitogo, San Francisco, Sariaya, and Unisan. One-third of the barangays in Quezon are coastal, and the rest are located in interior areas. There are more interior barangays than coastal barangays, except in Padre Burgos and Pitogo. Marinduque Province has four coastal municipalities-Boac, Mogpog, Sta. Cruz, and Torrijos. Batangas Province has only the municipality of San Juan along Tayabas Bay.

Tayabas Bay is surrounded by a coastline of about $525.9 \mathrm{~km}$. Out of these, $310.4 \mathrm{~km}$ lie within Quezon, 179.5 $\mathrm{km}$ within Marinduque, and $36 \mathrm{~km}$ within Batangas. The municipality of Sta. Cruz, Marinduque has the longest coastline of $106.5 \mathrm{~km}$ and has the most number of coastal barangays, including several small islands. In Quezon, Pagbilao has the longest coastline of about $56.4 \mathrm{~km}$.

The Silag Reef in Unisan, Quezon, has a "fair to good" coral cover. Seagrass communities in Pagbilao and Padre Burgos, Quezon, have been identified as nursery and breeding grounds for major commercial fishes, which can be declared as sanctuaries. Potential sites for sea farming or mariculture are also found along Padre Burgos and Pagbilao. Kapis shells thrive in the sandy and muddy areas of Malatandang in Unisan, Quezon, which 
Table 2. Fisher's density, fishing boat density, fishing gear density (number per kilometer of coastline), fishers per boat ratio, and gear per boat ratio per municipality of Tayabas Bay.

\begin{tabular}{lcccccc}
\hline Municipalities & $\begin{array}{c}\text { Fishers/ } \\
\text { km }\end{array}$ & $\begin{array}{c}\text { Fishing boat/ } \\
\text { km }\end{array}$ & $\begin{array}{c}\text { Fishing Gears/ } \\
\text { km }\end{array}$ & $\begin{array}{c}\text { Fisher/boat } \\
\text { ratio }\end{array}$ & $\begin{array}{c}\text { Gears/fisher } \\
\text { ratio }\end{array}$ & $\begin{array}{c}\text { Gear/boat } \\
\text { ratio }\end{array}$ \\
\hline Agdangan & 27 & 39 & 65 & 1 & 3 & 1.7 \\
Catanauan & 52 & 19 & 41 & 3 & 1 & 2.1 \\
Gen. Luna & 71 & 23 & 19 & 3 & 1 & 0.8 \\
Lucena & 88 & 45 & 34 & 2 & 1 & 0.8 \\
Macalelon & 85 & 43 & 45 & 2 & 1 & 1.0 \\
Mulanay & 35 & 36 & 47 & 1 & 1 & 1.3 \\
Padre Burgos & 31 & 20 & 18 & 2 & 1 & 0.9 \\
Pagbilao & 9 & 22 & 29 & 1 & 3 & 1.4 \\
Pitogo & 18 & 10 & 10 & 2 & 1 & 1.0 \\
San Francisco & 20 & 17 & 14 & 1 & 1 & 0.8 \\
Sariaya & 23 & 17 & 21 & 1 & 1 & 1.2 \\
Unisan & 43 & 20 & 24 & 2 & 1 & 1.2 \\
\hline Total & $\mathbf{3 4}$ & $\mathbf{2 3}$ & $\mathbf{2 8}$ & $\mathbf{1 . 4 7}$ & $\mathbf{0 . 8 1}$ & $\mathbf{1 . 1 9}$ \\
\hline
\end{tabular}

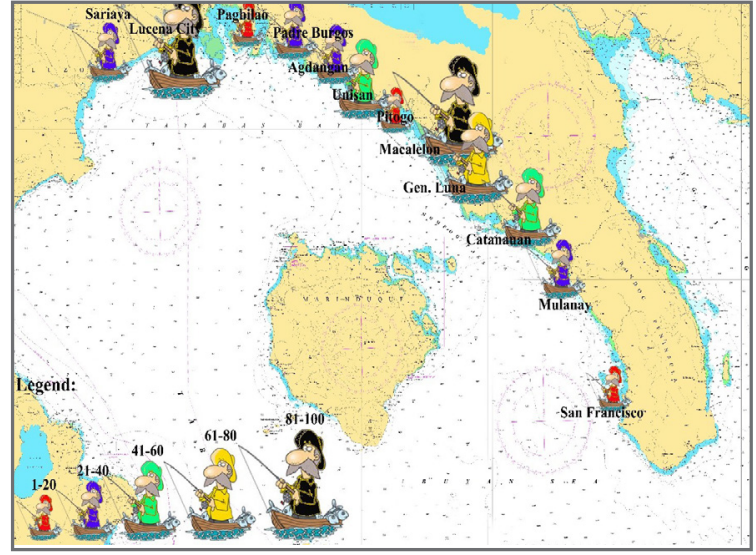

Figure 3. Fisher's density per municipality in Tayabas Bay.

can be regulated as they are gathered by baby trawlers which harvest even the very young ones. Bangus, prawn, and grouper fry are found in the same areas but are reportedly in danger of extinction because of the rampant use of dynamite and cyanide. Hence, the need to develop the will and commitment of the LGUs and fisherfolk to manage and enforce existing laws.

In the 2010 National Statistics Office Census of Population Survey, Tayabas Bay had a total coastal population of 409,000 comprising 82,000 households (NSCB 2010). Twenty-five percent of the households or around 20,500 were fishing households, that is, households with at least one family member engaged in a fishing activity.

This technical paper discusses the results of the 10-year (January 2004 to December 2013) assessment of the fisheries of Tayabas Bay to determine the current status and level of exploitation, and measure the effects of interventions introduced and implemented in the Bay and its surrounding or adjacent waters of the provinces of Quezon, Marinduque and Batangas. Eventually, an evaluation of economic loss caused by destructive fishing gear/method shall be determined and estimated in order to limit or stop the rampant use of destructive fishing gear or fishing methods.

\section{Objectives}

\section{Long-Term}

- Generate reliable data as a basis for the formulation of sound management and conservation policies for the attainment of sustainable production of the region's marine fisheries.

\section{Short-Term}

- Determine the number of fishing gears and boats;

- Map fishing area and identify fish landing sites;

- Determine the current levels of production, and effort, and their relationship;

- Estimate population parameters of the major marine resources in Tayabas Bay;

- Understand recruitment patterns of dominant fish species;

- Identify fishery issues and conflicts; and

- Recommend appropriate management options for the coastal waters of Tayabas Bay that would lead to the formulation of appropriate strategies.

\section{METHO D O L O G}

This study focuses on the production from the 16 municipalities of Quezon and one municipality at Batangas from January 2004 to December 2013. Collection of catch and effort statistics of all gears were undertaken by four enumerators at the Dalahican Fish Port at Lucena City. The fish port is being managed by the Philippine Fisheries Development Authority (PFDA). The other two sampling sites monitored were at Matandang Sabang Kanluran and Masaka at Catanauan, Quezon. Majority or almost all of the commercial and municipal fishing boats operating at Tayabas Bay unload their catch in these landing areas.

\section{Data Collection}

Secondary information about Tayabas Bay, especially on the demographic, labor force and employment data, were collected and compiled. The rest 
of the data were collected from primary sources. For the current information about the resources, sampling landing sites were identified, and standard methods of sampling and data processing were followed. Fish landing surveys were undertaken at the following landing sites: Dalahican, Lucena City; Matandang Sabang Kanluran; and Masaka, Catanauan. Sampling covered a 10-year period, from January 2004 to December 2013. The 10year fisheries and biological data collected were compiled and analyzed.

Fishing boat and gear inventory were conducted by the enumerators for 30 days in 16 municipalities and one city along Tayabas Bay, in coordination with the local barangay officials, to determine the amount of fishing in Tayabas Bay. Such information is vital in assessment, particularly in the estimation of production.

\section{Data Analysis}

Survey results raised per month by gear by landing center were added to obtain the annual yield from the three landing centers and then raised to the whole bay by using the information on gear counts.

For the purpose of standardization of effort and catch per unit effort, all data were transformed into Bottom Set Gillnet (BSGN) units, one of the dominant gears used in Tayabas Bay. The average catch per unit effort (CPUE) of BSGN was divided to the annual estimated yield to determine the total annual effort in terms of the number of boat landings of BSGN.

An estimate of the present Maximum Sustainable Yield (MSY) was done using the Schaeffer and Fox Models:

$\begin{array}{ll}\text { Schaefer } & \mathrm{Y}=\mathrm{af}+\mathrm{bf} 2 \\ \text { Fox } & \mathrm{Y}=\mathrm{fe}(\mathrm{a}+\mathrm{bf}) \\ \text { where: } & \mathrm{Y}=\text { Yield } \\ & \mathrm{a}=\text { intercept } \\ & \mathrm{b}=\text { slope } \\ & \mathrm{f}=\text { effort. }\end{array}$

The Effort used in the estimation of MSY is the total gross tonnage of all fishing boats operating in the bay.

The formula used in computing the exploitation rate $(\mathrm{E})$ is $\mathrm{E}=\mathrm{F} / \mathrm{M}+\mathrm{N}$ or $\mathrm{E}=\mathrm{F} / \mathrm{Z}$. The standard $\mathrm{E}$ value is 0.5 . If the value obtained is less than 0.5 , the resource is still unexploited. However, if the value is more than 0.5 , the resources/stocks are being exploited beyond their optimum yield.

Population parameters were estimated using the FAO ICLARM Stock Assessment Tools (FiSAT) by Gayanilo et al. (1996). This tool was also used to analyze the length frequency data of some selected dominant species found in Tayabas Bay. Some file manipulations, like running average of three and adjustment of class intervals, were used to emphasize the modes and increase the number of points to be used. Powell Wetherall's Plot (Powell 1979; Wetherall 1986) was used to estimate the mean asymptotic length $\left(\mathrm{L}_{\infty}\right)$, while the extreme value theorem (Formaccion et al. 1991) was used for estimating the Lmax. The curvature parameter $(\mathrm{K})$ of the VBGF, when $\mathrm{L}_{\infty}$ is given, was estimated using the $\mathrm{K}$-scan and curve fitting by eye routines of the ELEFAN I methodology (Pauly and David 1981).

Using the estimates of the growth parameters, $\mathrm{L}_{\infty}$ and $\mathrm{K}$, an analysis of the seasonal recruitment pulse was performed using the Recruitment Pattern methodology as proposed by Pauly (1984) through the reverse projection of the restructured data thru the time axis.

The natural mortality (M) was estimated using Pauly's empirical equation (Pauly 1980), i.e.,

$$
\begin{gathered}
\log (\mathrm{M})=-0.0066-0.27 \log \left(\mathrm{L}_{\infty}\right)+0.6543 \log (\mathrm{K})+ \\
0.4634 \log (\mathrm{T})
\end{gathered}
$$

where $\mathrm{L}_{\infty}$ (in $\mathrm{cm}$ ) is the asymptotic length, $\mathrm{K}$ is the curvature parameter of the VBGF, and $\mathrm{T}$ is the mean annual habitat temperature taken as 28 .OoC. The length converted catch curve (Pauly 1984; Edralin et al. 1988) was employed to estimate the total mortality $(\mathrm{Z})$, where the fishing mortality (F) of the fully-exploited length groups, can be deducted (i.e., $\mathrm{M}=\mathrm{Z}$ - F); and exploitation rate (E) was obtained by dividing $\mathrm{F}$ by $\mathrm{Z}$ computed for each species (Beverton and Holt 1956; Pauly 1984; Pauly and Soriano 1986; Silvestre et al. 1991).

The growth performance index $\varnothing^{\prime}=\log 10 \mathrm{~K}+$ $2 \log 10 \mathrm{~L}_{\infty}$ (Pauly and Munro 1984) was used to compare the growth performance of species studied with previous estimates contained in FishBase (Froese and Pauly 1998).

Other than the analysis of catch and effort, an analysis of the biological parameter coefficients of important species was also done. This component of stock assessment gives information on the values of the species parameters which, when compared to standard values, give the status of a particular resource. Optimum fishing mortality and optimum size of capture can be predicted, just as the potential yield and optimum effort are determined in the analysis of catch and effort component.

For instance, one of the standard values referred to for a stock that is optimally exploited is: fishing mortality (F) is about equal to natural mortality (M) or Fopt $=\mathrm{M}$ and exploitation rate, Eopt $=0.5$ (Gulland 1971).

\section{RESULTS AND DISCUSSION}

The Tayabas Bay was one of the priority bays under the Fisheries Sector Program in 1987 and the Fisheries Resource Management Project in 1997 (FRMP 2003; DA 1991). These projects were implemented to address the major problems identified in the sector study of the Asian Development Bank (ADB 2007): resource depletion in the coastal zone, widespread environmental damage, poverty among municipal fisherman, low productivity of aquaculture and limited utilization of offshore and Exclusive Economic Zone (EEZ) waters by commercial fishermen. In BFAR Region IV-A, four priority bays qualified for the criteria, namely, Manila 
Table 3. Comparitive results on number of species and fish groups (Jeremias and Ganaden 1989, and this study).

\begin{tabular}{|c|c|c|c|}
\hline \multirow[b]{2}{*}{ Family } & \multicolumn{2}{|c|}{ Species per Family (no.) } & \multirow[b]{2}{*}{ Fish groups } \\
\hline & \begin{tabular}{|c|} 
1983-1988 \\
(Jeremias \& \\
Ganaden)*
\end{tabular} & This Study & \\
\hline Carangidae & 21 & 36 & Jacks, trevallies, scads, hardtail, pomfrets, queen fis hes \\
\hline Serranidae & 10 & 29 & Groupers, seabas ses \\
\hline Scombridae & 16 & 14 & Kawakawas, mackerels, tunas \\
\hline Mullidae & 5 & 12 & Goatfishes \\
\hline Nemipteridae & 10 & 16 & Whiptails, threadfin breams \\
\hline Lutjanidae & 6 & 23 & Snappers, red snappers, other s nappers \\
\hline Scaridae & 1 & 12 & Parrot fis hes \\
\hline Lethrinidae & 3 & 9 & Emperors, pigface breams, large-eye breams \\
\hline Siganidae & 1 & 12 & Spinefoots \\
\hline Mugilidae & 3 & 7 & Mullets \\
\hline Acanthuridae & 3 & 7 & Surgeonfis hes, unicomfis hes \\
\hline Clupeidae & 7 & 8 & Sardines, s ardinellas \\
\hline Terapontidae & 1 & 2 & Terapon perches, terapons \\
\hline Belonidae & 4 & 3 & Needlefishes \\
\hline Caesionidae & & 5 & Fus iliers \\
\hline Engraulidae & 3 & 4 & Anchovies \\
\hline Gerreidae & 1 & 4 & Mojarras \\
\hline Haemulidae & & 12 & Grunts, s weetlips, rubberlips, hotlips \\
\hline Leiognathidae & 2 & 7 & Slipmouths \\
\hline Priacanthidae & 1 & 3 & Bigeyes, glass eyes, bulls eyes \\
\hline Ps ettodidae & 4 & 2 & Flatfishes \\
\hline Other Families & 54 & 130 & \\
\hline Total & 156 & 357 & \\
\hline
\end{tabular}

Bay, Calauag Bay, Tayabas Bay and Ragay Gulf. The Tayabas Bay is also one of the pilot bays where the Unified Municipal Fishery Ordinance was adopted and implemented by the LGUs surrounding the Bay since May 2003.

The Fisheries Resource Management Project put emphasis on data management, CRM planning and implementation, fisheries legislation and regulation, community-based law enforcement, nearshore monitoring, and control and surveillance.

Income diversification was promoted for municipal fisherfolk by organizing self-reliant community groups, promoting microenterprises and supporting mariculture development. Livelihood projects like aquasilviculture, culture of grouper in cages, and other aquaculture technologies were implemented, including the establishment of two Mariculture Parks at Padre Burgos and Tagkawayan, Quezon.

Capacity building training programs were done to build up the capacities of government agencies at the national, regional and local levels. Training courses and seminars were implemented. Various training on Deputy Fish Warden, Law Enforcement, and Organizations/Strengthening of Fisheries and Aquatic Resources Management Councils (FARMCs) at the barangay, municipality, provincial, and regional levels were undertaken. Training/Orientation on RA 8550 and FAO 116 were done resulting in a more organized and strengthened FARMC and LGU partnership. The output of this initiative was the formulation of a Unified Fishery Ordinance (UFO) for Tayabas Bay which was enforced/implemented in 2003. The management and conservation of the bay then was done in an integrated manner (Section 16 of RA 8550).

After the project termination in 2004, BFAR $4 \mathrm{~A}$ streamlined the project and activities into its regular program. Eight Marine Protected Areas/Fish Sanctuaries were established at Tayabas Bay. Livelihood projects were implemented through the distribution of fishery inputs (i.e., fishing gears, fingerlings dispersal, post-harvest training and marketing assistance).

In 2012, 40 sets of bottom set gill nets and 50 crab pots were given to the fisherfolk beneficiaries of Lucena City. Likewise, nine hectares of coastal areas at Padre Burgos, Pitogo and General Luna were planted with 30,000 mangrove propagules as one of the mitigating measures of the impacts of climate change.

Three hundred ninety-one sets of bottom set gillnet, 100 fish pots, 86 crab pots, and 13 motor engines were provided to various beneficiaries around Tayabas Bay in 2013. Likewise, 2,000 pieces of mangrove propagules were planted to two hectares in the municipalities of Agdangan, Catanauan, Macalelon and Padre Burgos.

There are only a few documented studies on the fisheries of Tayabas Bay. Among the relevant studies are those of Warfel and Manacop (1950) which reported species composition, production by depth, and other parameters as a result of the exploratory otter trawl fishing. Manacop (1955) reported that Tayabas Bay is one of the good trawling grounds with a production rate of $400-600 \mathrm{~kg}$ catch per day. Ordoñez et al. (1977) conducted exploratory fishing and biological study on board the $\mathrm{R} / \mathrm{V}$ Researcher using Norwegian type of otter trawl in Tayabas Bay. The survey was done in connection with the Test-Fishing Program which aims to investigate further the economic potential of the country's fishing grounds. The emphasis was placed on the oceanographic aspects to establish inter-relationship between the environment and fishery resource in the area. The catch composition showed that the deeper waters are potentially promising with the yield of first-class fishes like crevalle (Caranx), mackerel (Rastrelliger), bream (Nemipterus), grouper 
(Epinephelus) and moonfish (Mene), although most of them were immature. This may suggest off-season for spawners and breeders, which is complemented by the absence of few fish eggs and larvae probably because it was not yet the peak of the spawning time. Likewise, some oceanographic factors may have affected their spawning activity, but also plankton abundance which is necessary for their existence. Low larval activities may have been due to these chain reactions, noting further that all the shallow shores of bays and coves in the marine waters of the country can be considered nursery areas (Ordoñez et al. 1977). Hernando and Flores (1981) noted that, based on the records of BFAR (1957-1976), Tayabas Bay ranked as the 11th fishing ground for squids in the Philippines. Aside from these, there are unpublished written reports based on field surveys conducted by several fishery biologists in the area. The existing fishery statistical baseline data, on the other hand, are poor and are not reliable to provide information for purposes of fish stock assessment (Villoso and Hermosa 1982).

Historical data on Tayabas Bay fisheries production is fragmented and insufficient to establish a reliable assessment of fisheries resources of the bay. Only commercial production data were compiled and published. Recognizing the importance of total production in resource assessment, in 1977 catch statistics were reformatted and arranged into 24 statistical areas; Tayabas Bay was considered as one of the statistical areas. Data in municipal fisheries were also collected and included in the annual statistical report after 1977. This improved annual fisheries production lasted only until 1986, due to change of administration which, normally, also brings about change of policies. In 1986, the Bureau of Fisheries and Aquatic Resources (BFAR) was merged with the Department of Agriculture (DA) as a staff bureau. Henceforth, the responsibility for the preparation of useful fishery statistics was transferred to the Bureau of Agricultural Statistics (BAS) which did not continue the frame of collection and publication on a statistical area. The annual fishery statistical report was again reclassified by BAS and organized by region. The data no longer indicated estimates on fishery production in each bay or by fishing grounds which resulted in a break on available fisheries production data for the bay. This methodology was employed until 1990, after which statistics were then reclassified by fishing ground. Furthermore, data on effort were not reflected in the fishery statistics; thus, they could not provide reliable estimates of the fishery potential of the bay. Nevertheless, based on available data, the total fishery production (commercial and municipal fishery) of Tayabas Bay is reported to decline from 1978 to 1987 (BFAR Fishery Statistics 1978-1987).

In 1983-1988, Jeremias and Ganaden made an analysis of catch, effort, catch per unit of effort, and relative abundance of catch of major gears operating in Tayabas Bay. The study focused on the operation of five major gears, namely commercial bag net, gillnet, beach seine, set long line, and fish corral. It recorded a fluctuating production representing the various unit fisheries which confirm the fully exploited situation of
Tayabas Bay. Furthermore, the increase in the catch of squid in the soft grounds where fish corrals are installed indicates a resource replacement when previously abundant species become less (Jeremias and Ganaden 1986). The abundance of squid has been established as an indicator of exploitation in the Gulf of Thailand.

It is necessary to identify various fisheries issues which affect the sustainability of marine fishery resources in the Tayabas Bay area. Some of the issues identified besetting the bay are destructive/illegal fishing methods, intrusion of commercial fishing vessels into municipal waters, and environmental concerns on the pollution caused by the Hopewell Coal Power Plant located at Isla Grande in Pagbilao, Quezon, which emits hazardous substances such as mercury, arsenic, and lead. Also, the high rate of sedimentation from Pagbilao and Macalelon Rivers has been associated with the degradation of the coral reef near the outfall of the said rivers.

In 2003, Perez et al. conducted a study on Community-Based Law Enforcement in Tayabas Bay with the findings that community law enforcers can help enforce the law, and those commensurate penalties must effect deterrence. Apprehension and filing of cases and conviction are not enough to deter violators of fishery law. The study recommended that stiffer penalties, in the form of imprisonment and confiscation of fishing boat and paraphernalia, be enforced to curb the illegal fishing practice, especially among repeat offenders.

The category of Tayabas Bay in 2011 was "moderately fished" area, with fisher density of around 34 fishers/km (based on Fox's definition of a "moderately fished" area, with 20-70 fishers/km coastline).

The average fisherman's density of $34 / \mathrm{km}$ for Tayabas Bay is below the estimates for other major fishing grounds like Lingayen Gulf with 78 (Silvestre et al. 1988) and the whole of Guimaras Strait with $98 / \mathrm{km}$ of coastline (Padilla et al. 1990, cited in Lachica-Aliño et al. 2001). This is also way lower than the fisher's density of other enclosed areas such as Manila Bay with 253 (Armada 1993). It is slightly higher than the estimate of 17 fishers per $\mathrm{km}$ of coastline in Honda Bay (Ramos et al. 2002) and Ormoc Bay with 22 fishers per $\mathrm{km}$ of coastline (Ingles 1992).

The average fisher to banca ratio is 1.47 for every small-scale fishing boat, and 15 fishers for every commercial vessel. The 1.47 fishers to banca ratio operating within the bay is higher than the computed ratio in the study of Lachica-Aliño et al. (2001). This is also relatively lower than that of other traditional fishing grounds in the country, such as Lingayen Gulf with 1.8 in 1998 (Silvestre et al. 1998) and San Pedro Bay with 1.9 in 1995 (Armada 1996).

The number of boats within the bay was 7,197 with 8,580 fishing gears being operated by 10,590 fishermen. It can be observed that Gen. Luna has a higher fisher to boat ratio due to the operation of ring net, a commercial gear in the area. In the case of artisanal (municipal, <3 GT), the average of three fishers to a boat was observed in Catanauan and Gen. Luna. 


\section{Boat and Gear Inventory}

Boat. Non-motorized and motorized boats are used in Tayabas Bay. The number of non-motorized boats in 2004 was 1,480; then it dropped to 915 in 2007 but increased to 1,330 boats in 2010 and 2,696 in 2012 (Figure 4). The same trend was observed for motorized boats.

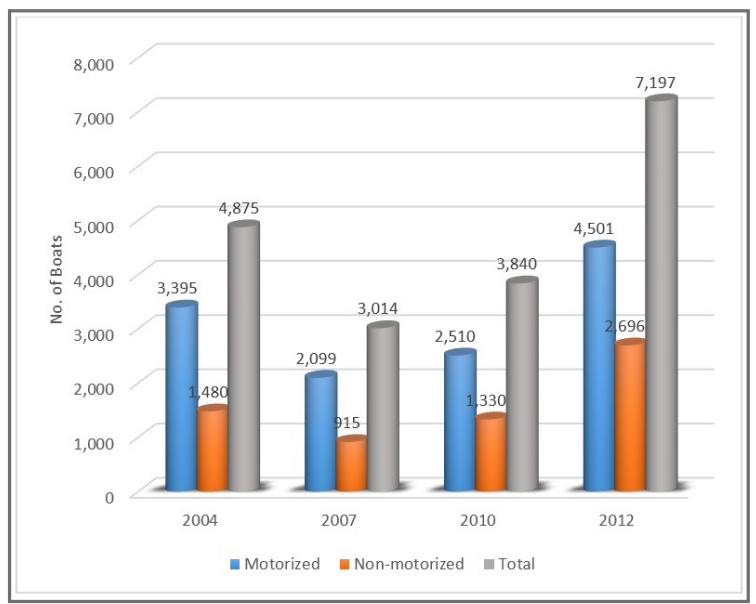

Figure 4. Inventory of boats in Tayabas Bay (2004, 2007, 2010 and 2012).

Gear Particulars. A total of 8,580 fishing gear units, composed of lines, nets, traps, and hand/gathering instruments, are operated in Tayabas Bay. The annual set of data showed that there was an increase of $14.3 \%$ in the number of fishing gear, particularly nets, while lines increased by $15 \%$, traps by $21.7 \%$, and hand instruments by $48.9 \%$. Figure 5 shows that nets comprise the majority of gears used by fishermen in the bay, followed by lines, traps, and hand/gathering instruments.

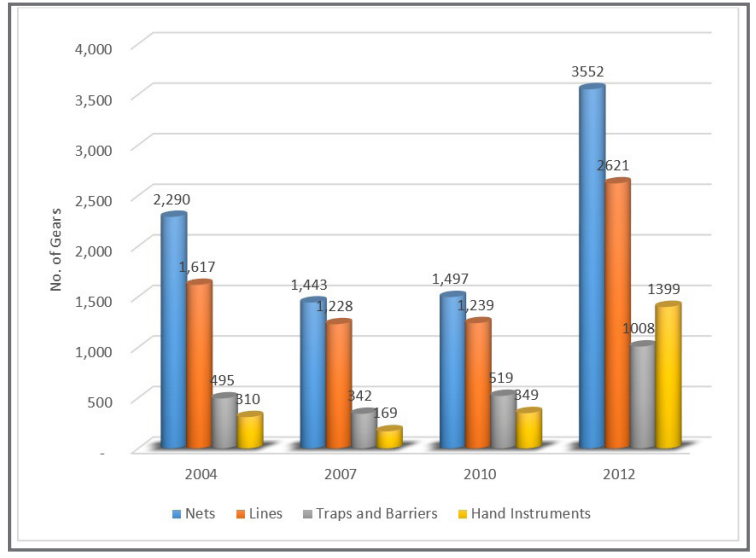

Figure 5. Number of fishing gear per category.

Catch Contribution by Gear. The production of Tayabas Bay is contributed mostly by purse seine, bottom gillnet, hook and line, lift net, drift gillnet, and baby lift net (Figure 6).

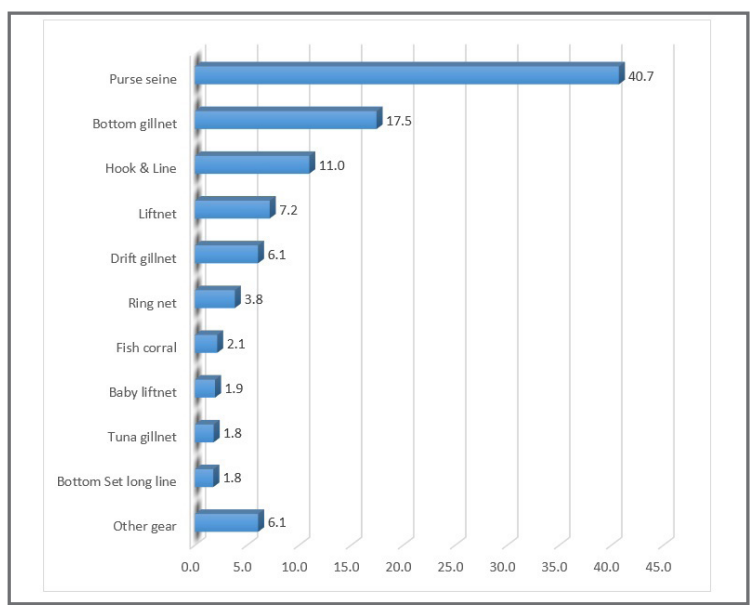

Figure 6. Percentage share of gear to the total fish production in Tayabas Bay (2004-2013).

Record of catches from 2004 to 2013 showed that purse seine contributed the highest yield (41\%) followed by bottom gillnet $(18 \%)$, hook and line $(11 \%)$, lift net (7\%), drift gillnet (6\%), and baby lift net (4\%). Minor gears (fish corral, baby lift net, tuna gillnet and bottom set long line) contributed only two percent.

\section{Annual Production}

Over the 10-year study, the average contribution of municipal production was $46 \%$, while the commercial fisheries production contributed 54\% (Figure 7). The trend of the commercial production was decreasing from 2004 to 2008 but increasing from 2010 to 2013, while that of the municipal production was fluctuating. The decrease in commercial fisheries production from 2004 to 2008 was attributed to the strict enforcement by the LGU of the total ban on the operation of commercial fishing vessels (CFVs) in the municipal waters.

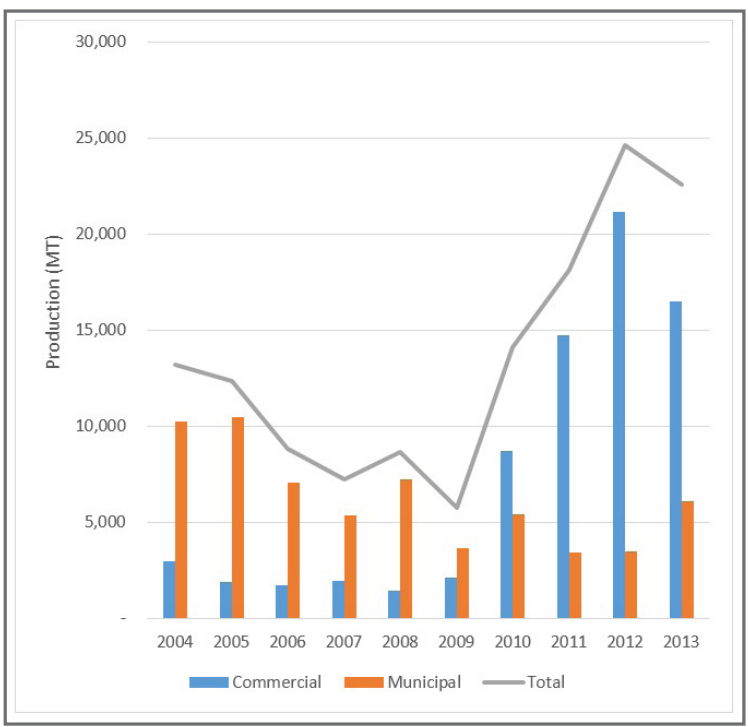

Figure 7. Estimated annual production of Tayabas Bay (2004- 2013). 


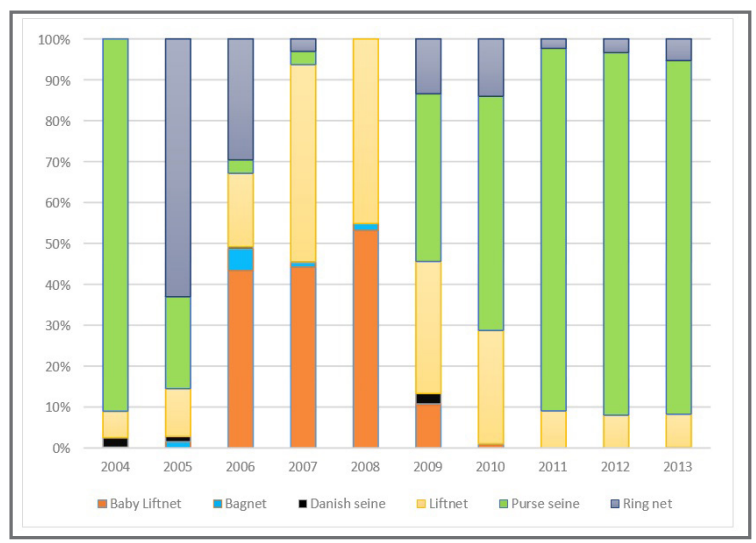

Figure 8. Operation of commercial gears over the 10-year study at Tayabas Bay.

The production of Tayabas Bay is not only influenced by weather condition, but also by some programs, projects, and policies implemented by the local Chief Executives, as mandated in Article 25, Rule V of the Implementing Rules and Regulation (IRR) of RA 7160 which provides "enforcement of fishery laws in municipal waters, including conservation of mangroves."

In 2003, Executive Order No. 24 was issued creating the Provincial Task Force for Fishery Conservation and Law Enforcement (PTFFCLF) to strengthen the law enforcement efforts of the province. The team was an inter-government and non-government collaboration between and among the LGUs, DENR, PNP-MARICOM, PIA, Tanggol Kalikasan, and BFAR. This was superseded by various Municipal and Provincial Resolutions for the establishment/creation of Integrated Resource Management Councils as provided in the IRR of RA 8550 or Philippine Fisheries Code of 1998.

Effort. The number of observed boat landings of all gears ranged from 13,746 in 2005 to 33,842 in 2013. For the purpose of correlating annual estimated production from the effort in terms of boat landings, it was standardized using bottom set gillnet (BSGN) units. Thus, the standardized annual estimated effort by bottom set gillnet ranged from 2,199,589 to 7,194,394 (Figure 9).

Catch and effort relationship. The trend of catch, effort, and catch per unit effort from 2004 to 2013 showed that an increase in catch could be attained by increasing effort, with fluctuating CPUE. Boat landing observations showed that the highest effort can sustain the maximum production level, estimated in this study at 622 MT.

Catch per unit effort by gear. Data on CPUE of some commercial gears showed a decreasing trend, such as in bag net (from $105 \mathrm{~kg}$ in 2004 to $71 \mathrm{~kg}$ in 2013) and lift net (from $221 \mathrm{~kg}$ in 2004 to $213 \mathrm{~kg}$ in 2013); and an increasing trend, such as in purse seine (from $4,738 \mathrm{~kg}$ in 2004 to $7,624 \mathrm{~kg}$ in 2013), Danish seine (108 kg in 2004 to $393 \mathrm{~kg}$ in 2010), and ring net (from $816 \mathrm{~kg}$ in 2005 to 907 $\mathrm{kg}$ in 2013).

For municipal gears, the CPUE of some of the most used gears showed a decreasing trend, notably in multiple hook and line (7 kg in 2004 to $6 \mathrm{~kg}$ in 2013), drift gillnet (53 kg in 2004 to $7 \mathrm{~kg}$ in 2013), and hook and line (9 $\mathrm{kg}$ in 2004 to $5 \mathrm{~kg}$ in 2013). An increasing trend was observed in bottom set gillnet ( $3 \mathrm{~kg}$ in 2004 to $5 \mathrm{~kg}$ in 2013), spear gun (7 kg in 2004 to $13 \mathrm{~kg}$ in 2013), and surface gillnet (4 kg in 2004 to $6 \mathrm{~kg}$ in 2013).

Seasonality of Catch. Tayabas Bay is classified under the Type IV climatic condition, that is, no dry season exists and a very pronounced rainy period prevails from November to January. Two pronounced monsoon winds affect the area, the southwest monsoon or "habagat" and the northeast monsoon or "amihan". Amihan begins in October and ends in May. During this period, fishing activities in the bay are prominent due to much calmer seas. As such, the period is considered as the peak fishing season in the area (Figure 10). However, fishing is highly reduced during the habagat (June to September) due to normally unstable sea condition.

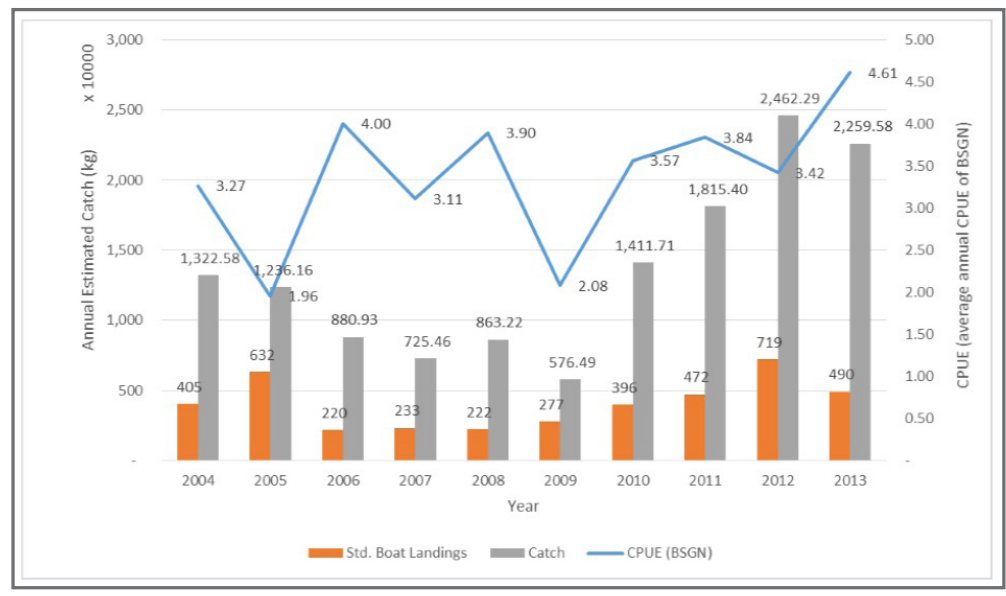

Figure 9. Relationship of catch and effort in Tayabas Bay (2004-2013). 


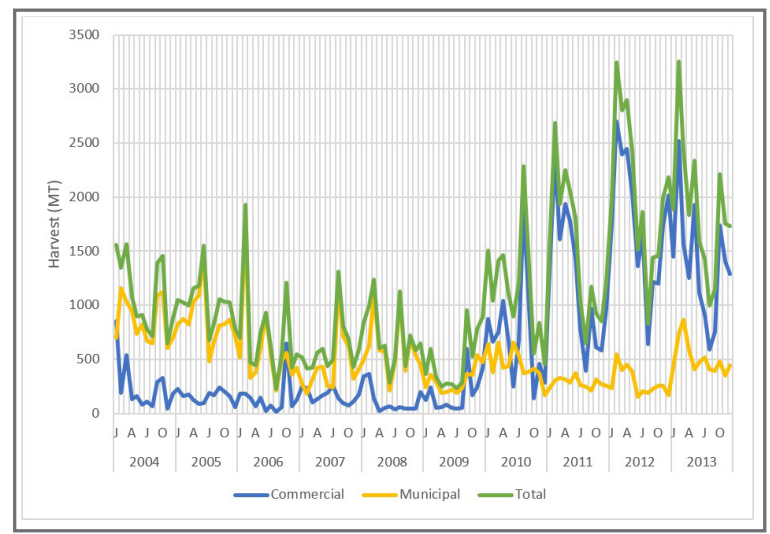

Figure 10. Monthly seasonality of landed catch of Tayabas Bay (2004-2013).

\section{Catch Composition}

In 2004, 220 species belonging to 57 families were identified in the three landing sites (Figure 11). Compared to the list in 2005, the number of fish species increased by $2.2 \%$ ( 230 species of fish belonging to 58 families), while the invertebrate species increased by 26.6\% (19 species belonging to 11 families). From 2004 to 2008 , there was an increasing trend in the number of species and families, probably due to the improvement and the capability to identify which may not have been efficient in the past years.

In the 10-year study, there was a fluctuation trend in the identified invertebrate species (Figure 12).

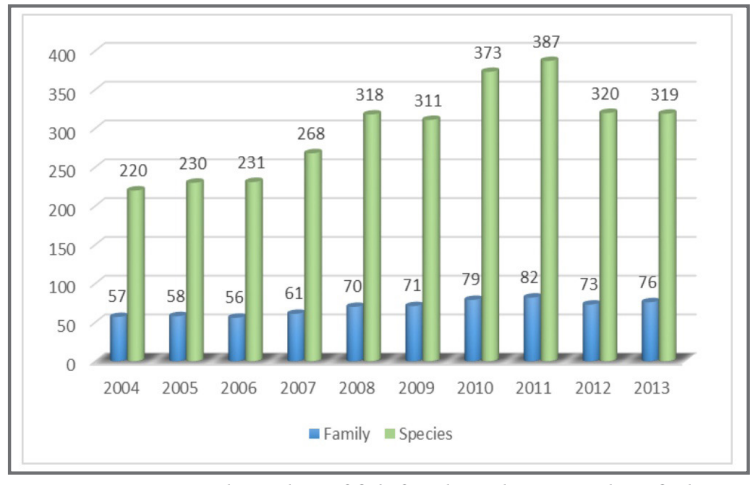

Figure 11. Annual number of fish family and species identified in Tayabas Bay.

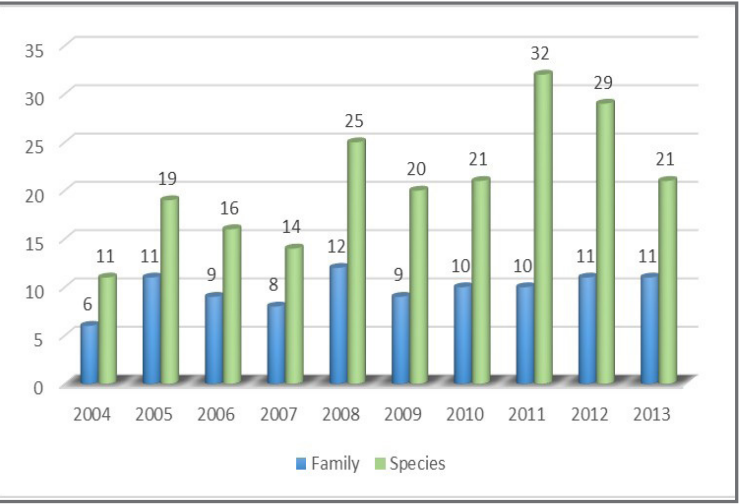

Figure 12. Number of invertebrate family and species identified in Tayabas Bay (2004-2013).

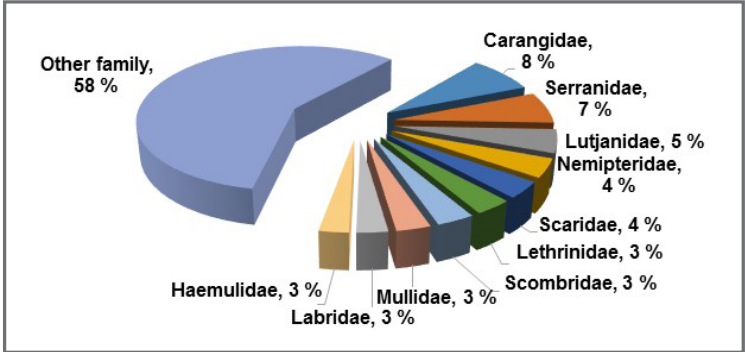

Figure 13. Relative abundance of fishes (by family) caught in Tayabas Bay (2004-2013).

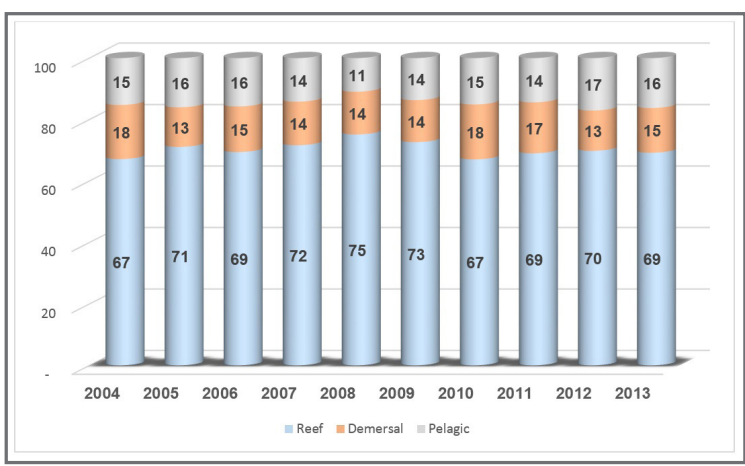

Figure 14. Percentage composition of pelagic, demersal, and reef fishes caught in Tayabas Bay (2004-2013).

\section{Relative Abundance by Family}

In terms of the number of species by family, Carangidae comprises eight percent of the species caught in Tayabas Bay from 2004 to 2013, followed by Serranidae (7\%), Lutjanidae (5\%), Nemipteridae (5\%), and Scaridae (4\%) (Figure 13).

\section{Pelagic, Demersal and Reef Fishes}

Based on the 10-year data, reef fishes dominated the catch with an average of $70.1 \%$, while demersal fishes and pelagic fishes accounted for $15.1 \%$ and $14.8 \%$, respectively (Figure 14).

\section{Most Abundant Species Caught}

Sardinella lemuru dominated the catch (14\%), 


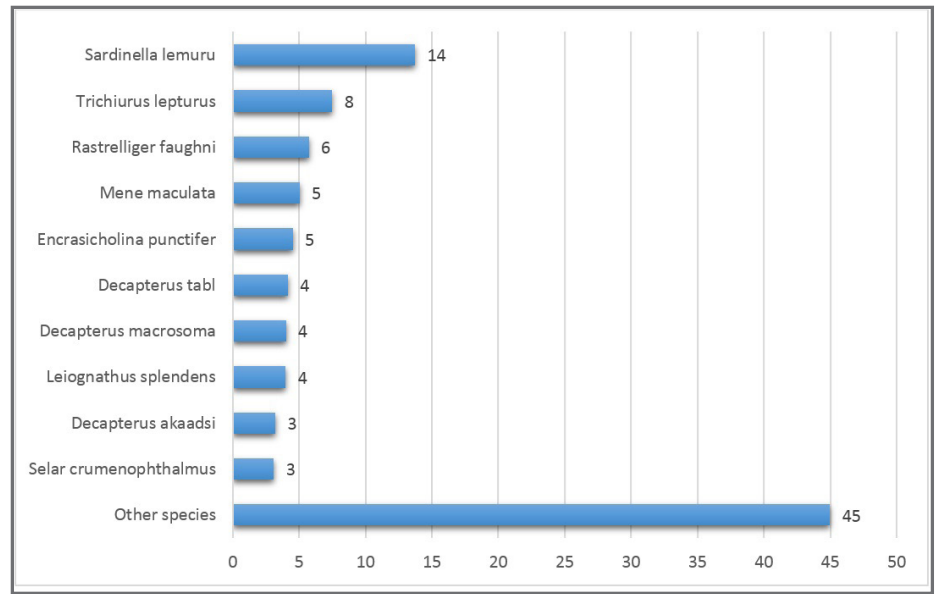

Figure 15. Most abundant species caught in Tayabas Bay (2004-2013).

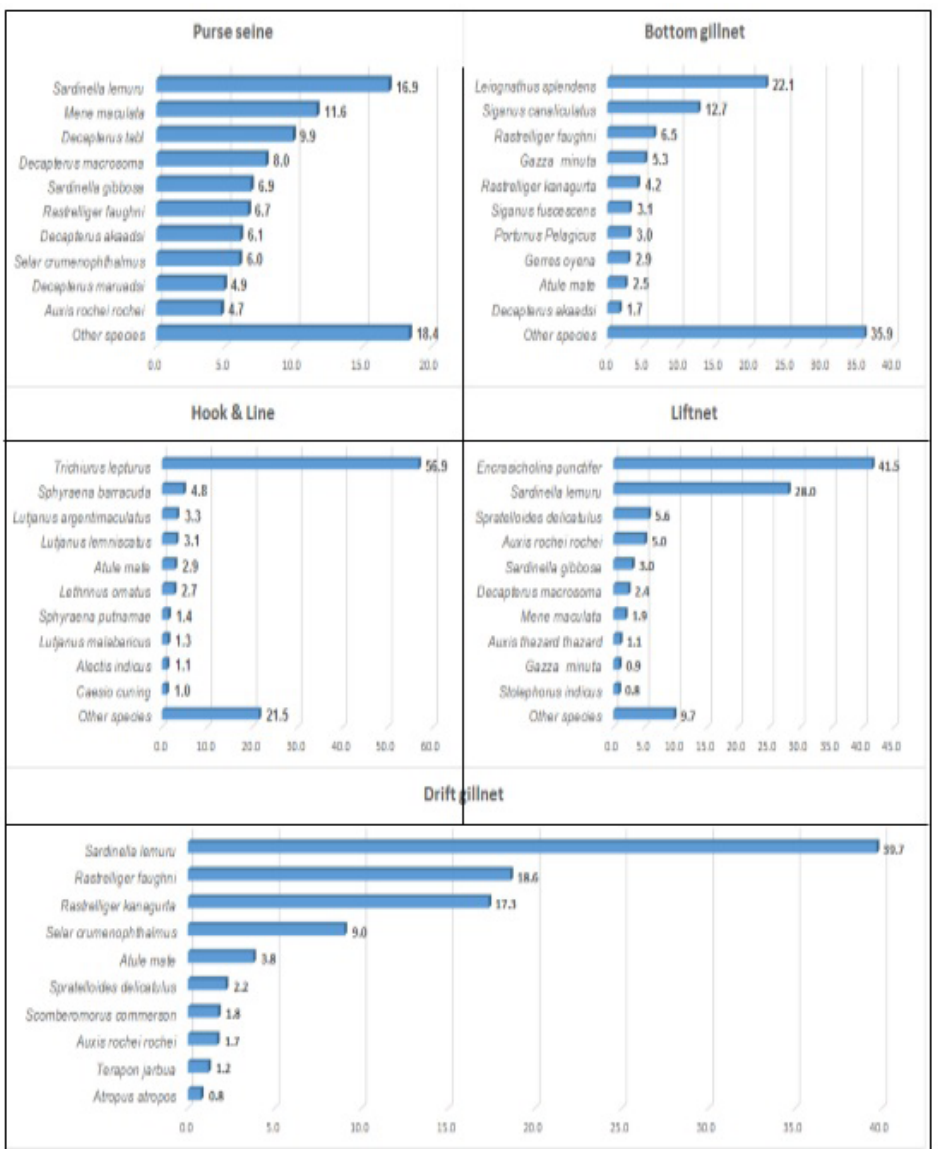

Figure 16. Composition of top 10 species caught by five major gears operating in Tayabas Bay (2004-2013).

followed by Trichiurus lepturus (8\%), Rastrelliger faughni (6\%), Mene maculata (5\%), and Encrasiocholina punctifier (5\%). Most of the commercially exploited fish species in Tayabas Bay are small pelagic species (Figure 15). Demersal fish species and reef fishes also contribute to the commercial production in Tayabas Bay, although in small quantities only.

\section{Species Composition of Major Gears}

The study of Jeremias and Ganaden in 1983 to
1988 showed that major gears have a high percentage composition of pelagic species that belong to higher trophic level, such as Katsuwonus pelamis, Auxis thazard, Rastrelliger spp., and Decapterus spp.

\section{Relative Abundance of Species per Fishing Gear}

Data on the relative abundance of species per fishing gear showed variation in species composition. For the purse seine, Sardinella lemuru was the most abundant species; bottom gillnet, Leiognathus splendens; hook and 
line, Trichiurus lepturus; lift net, Encrasicholina punctifer; and drift gillnet, Sardinella lemuru (Figure 16). Small pelagics were predominated by large pelagics from 2004 to 2013 .

\section{Size (Length) of Fish Species Caught by Different Gear Types}

Based on 2006-2013 data, nets (i.e., bag net, bottom set gillnet, drift gillnet, and lift net) and purse seine generally catch a higher number of small-sized fishes compared to the other types of gear targeting the same species.

For Sardinella lemuru, large sizes were mainly caught by purse seine, lift net, and bag net (Figure 17). The average size of the species at first maturity is $14 \mathrm{~cm}$, thus contributing to the population before being caught.

Figure 18 shows that high percentage of largesized Decapterus macrosoma was caught by purse seine.

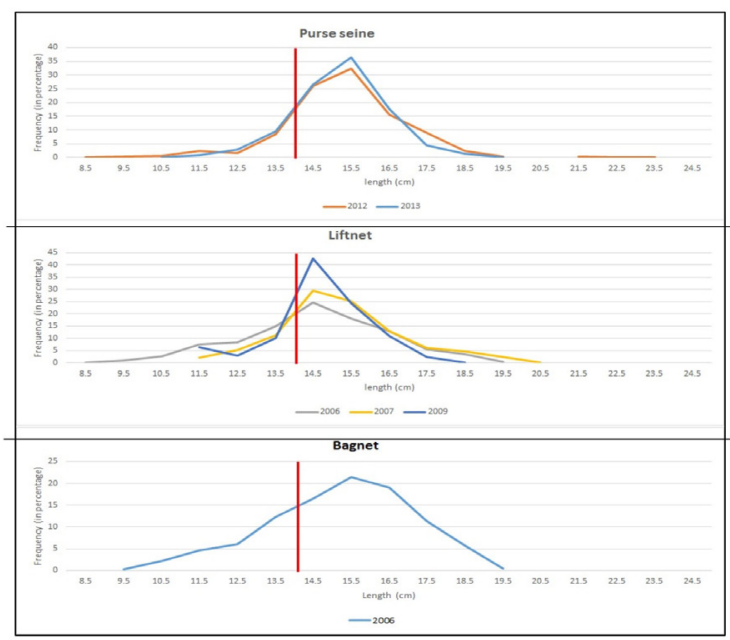

Figure 17. Length frequencies of Sardinella lemuru caught by different types of gear in Tayabas Bay.

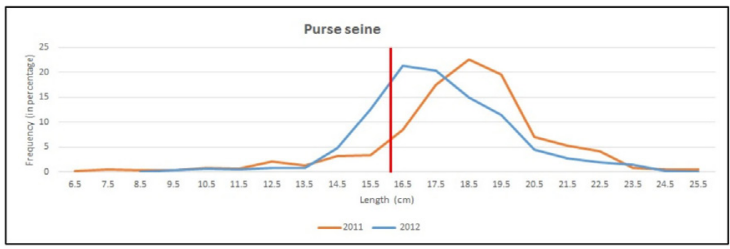

Figure 18. Length frequencies of Decapterus macrosoma caught by purse seine in Tayabas Bay.

Majority of the catches of purse seine were large in size.

The bottom set gillnet and lift net caught the small-sized Gazza minuta in Tayabas Bay (Figure 19). Aside from G. minuta, the bottom set gillnet also catches small-sized Leiognathus equulus (Figure 20). This means that these gears caught these species before they become sexually mature, and thus they are not able to contribute to the recruitment process.

From 2010 to 2012, the majority of Leiognathus splendens were caught by bottom set gillnet before reaching sexual maturity (Figure 21) while Nemipterus

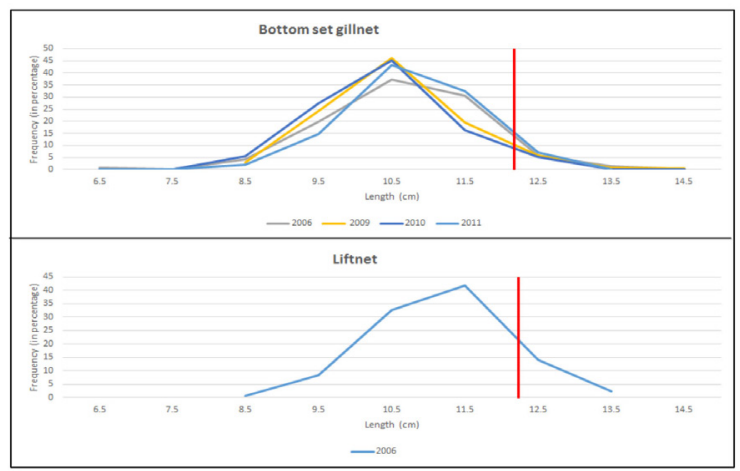

Figure 19. Length frequencies of Gazza minuta caught by different types of gear in Tayabas Bay.

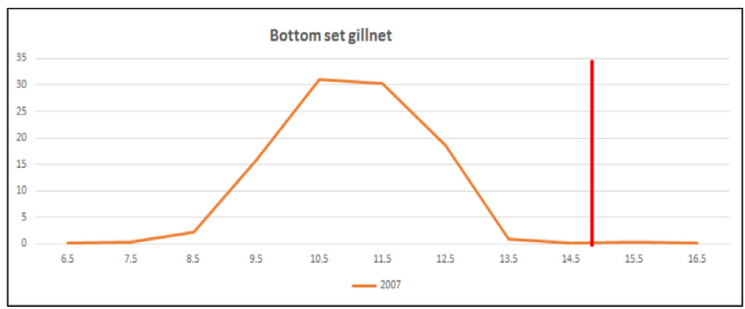

Figure 20. Length frequencies of Leiognathus equulus caught by bottom set gillnet in Tayabas Bay.

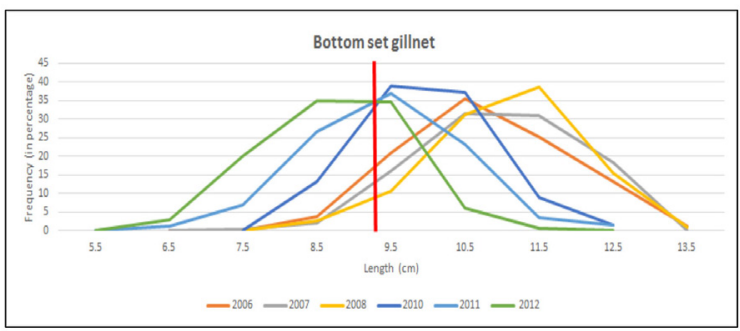

Figure 21. Length frequencies of Leiognathus splendens caught by bottom set gillnet in Tayabas Bay

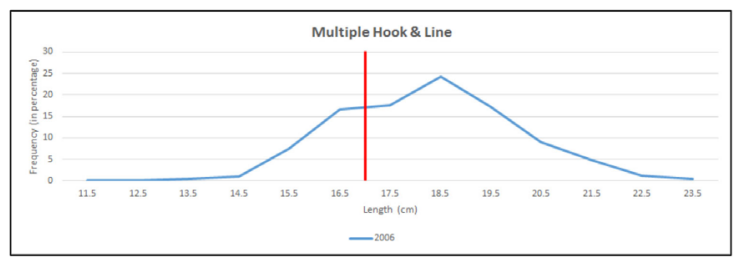

Figure 22. Length frequencies of Nemipterus bathybius caught by multiple hook and line in Tayabas Bay.

bathybius were caught by multiple hook and line after reaching the length at first maturity (Figure 22).

For Nemipterus nemurus, larger sizes were mainly caught by multiple hook and line and bottom set gillnet, while large-sized Rastrelliger faugni were caught by drift gillnet and bottom set gillnet (Figures 23-24).

Rastrelliger kanagurta reached sexual maturity before they were caught by drift gillnet and bottom set gillnet, thus contributing to the recruitment process (Fig. ure 25). Purse seine catches more of the larger sizes of 


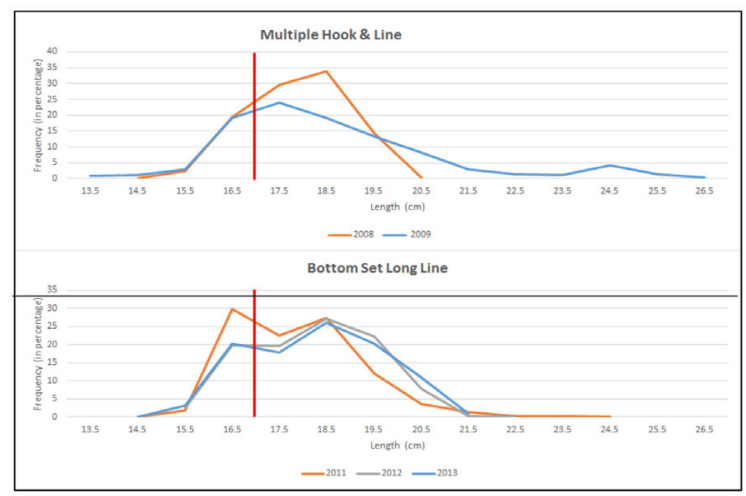

Figure 23. Length frequencies of Nemipterus nemurus caught by different types of gear in Tayabas Bay.

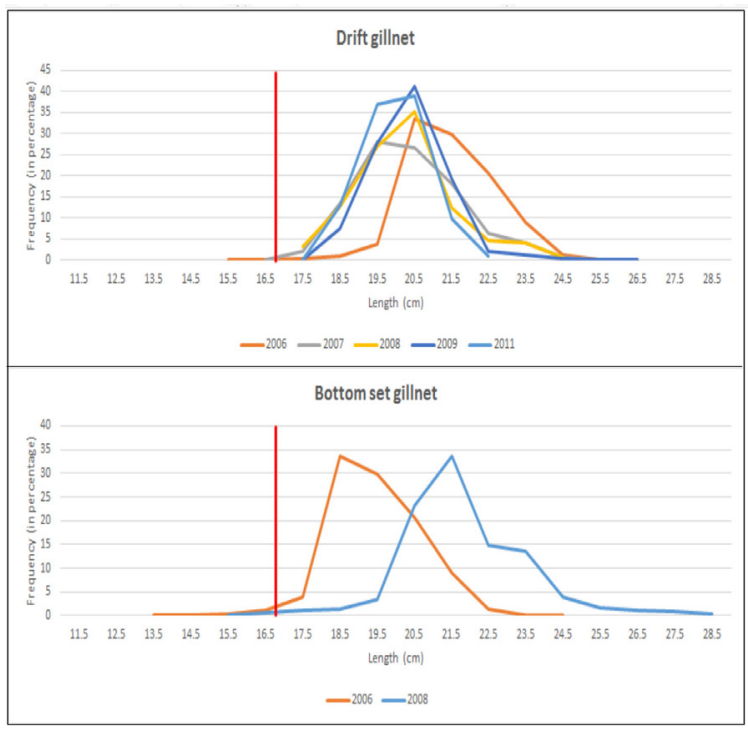

Figure 24. Length frequencies of Rastrelliger faughni caught by different types of gear in Tayabas Bay.

Sardinella gibbosa (Figure 26).

Large-sized Selar crumenopthalmus were caught by purse seine (Figure 27), while Siganus canaliculatus were caught by bottom set gillnet before reaching sexual maturity (Figure 28).

A high percentage of large-sized Siganus fuscescens was caught by bottom set gillnet and spear gun (Figure 29), while a majority of the bottom set gillnet catch were smaller sizes of Upeneus sulphureus (Figure $30)$.

\section{Population Parameters}

Nine pelagic species (Sardinella lemuru, $S$. gibbosa, Cypselurus naresii, Decapterus macrosoma, D. maruadsi, D. tabl, Rastrelliger faughni, R. kanagurta and Selar crumenopthalmus) and seven demersal species (Gazza minuta, Leiognathus equulus, L. splendens, Nemipterus bathybius, N. nemurus, Siganus canaliculatus and Upeneus sulphureus) were analyzed for biological parameters. Table 4 shows the species with estimated $\mathrm{E}$ values which are within the optimum values as suggested

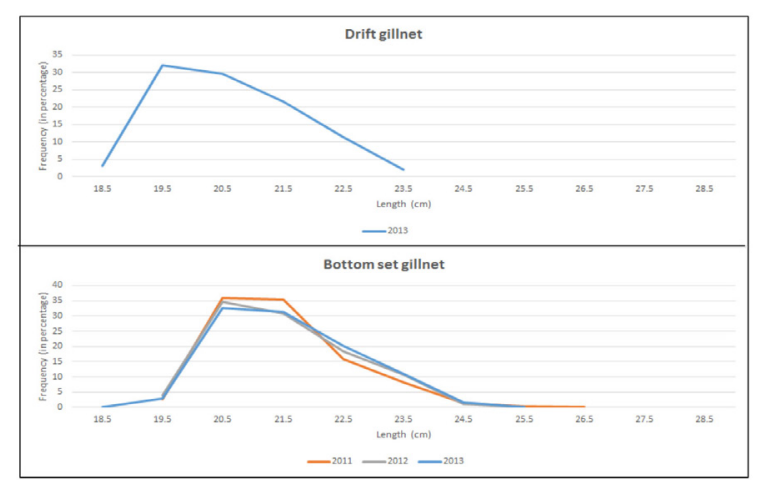

Figure 25. Length frequencies of Rastrelliger kanagurta caught by different types of gear in Tayabas Bay.

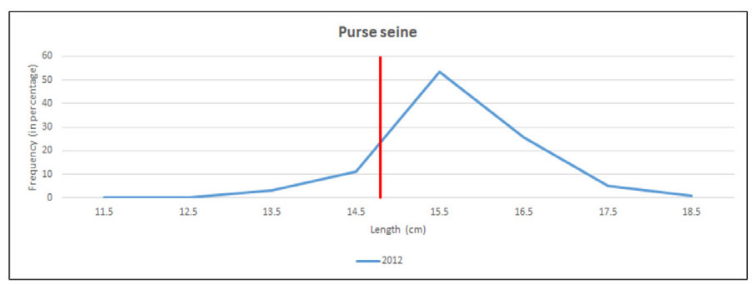

Figure 26. Length frequencies of Sardinella gibbosa caught by purse seine in Tayabas Bay.

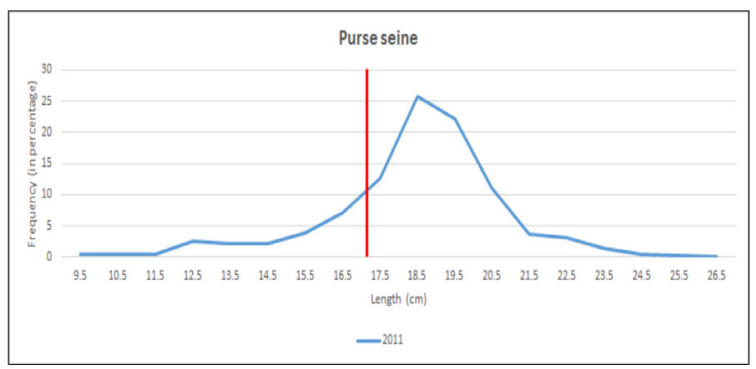

Figure 27. Length frequencies of Selar crumenophthalmus caught by purse seine in Tayabas Bay.

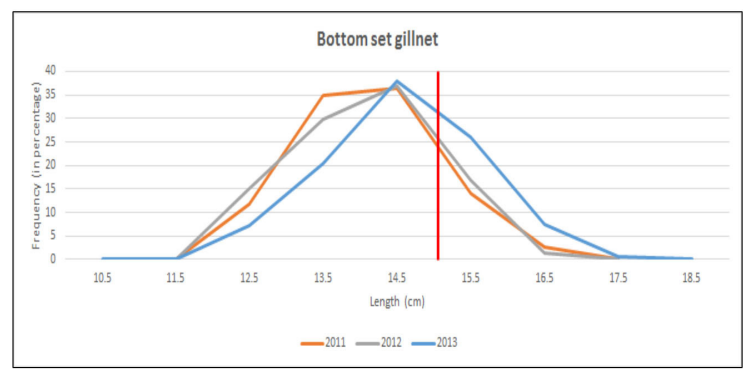

Figure 28. Length frequencies of Siganus canaliculatus caught by bottom set gillnet in Tayabas Bay.

by Gulland (1971).

Growth. Growth parameter $(\mathrm{K})$ is a relative index of the rate of growth, usually between values of 0.4 and 2.0, which describes the species to be fast growing (more than 1.0) or slow growing (less than 1.0). Based on this, Decapterus macrosoma, D. maruadsi, Rastrelliger faughni and Selar crumenopthalmus are slow-growing species, while Sardinella lemuru, Cypselurus naresii, Rastrelliger kanagurta, Gazza minuta, Leiognathus 
Table 4. Summary of growth ( $\mathrm{L}_{\infty}$ and $\left.\mathrm{K}\right)$ and mortality $(\mathrm{Z}, \mathrm{M}$ and $\mathrm{F})$ parameters, exploitation ratios $(\mathrm{E})$ and number of recruitment pulses (NRP) for selected species exploited in Tayabas Bay (2006-2013).

\begin{tabular}{|c|c|c|c|c|c|c|c|c|c|c|c|}
\hline Species & Year & Gear & $\mathbf{L}_{\infty(\mathrm{cm})}$ & $\begin{array}{c}\mathbf{L}_{\max } \\
(\mathrm{cm})\end{array}$ & $\begin{array}{c}\mathbf{K} \\
(\text { year-1) }\end{array}$ & $\begin{array}{c}\mathrm{Z} \\
(\text { year-1) }\end{array}$ & $\underset{(\text { year-1) }}{\mathbf{M}}$ & $\begin{array}{c}\mathbf{F} \\
(\text { year-1) }\end{array}$ & $\mathbf{E}$ & NRP & $\varnothing$ \\
\hline Sardinella lemuru & 2006 & $\mathrm{LN}$ & 20.36 & 20.4 & 0.88 & 2.43 & 1.83 & 0.6 & 0.25 & 1 & 2.562 \\
\hline Sardinella lemuru & 2009 & $\mathrm{LN}$ & 19.08 & 18.47 & 0.67 & 2.37 & 1.56 & 0.81 & 0.34 & 1 & 2.387 \\
\hline Sardinella lemuru & 2013 & PS & 21.15 & 19.75 & 0.48 & 2.42 & 1.22 & 1.2 & 0.5 & 2 & 2.332 \\
\hline Sardinella gibbosa & 2012 & PS & 19.54 & 19.05 & 0.77 & 3.04 & 1.7 & 1.34 & 0.44 & 1 & 2.468 \\
\hline Cypselurus naresii & 2009 & SGN & 24.9 & 24.58 & 1.8 & 5.86 & 2.76 & 3.1 & 0.53 & 1 & 3.048 \\
\hline Rastrelliger faughni & 2006 & BSGN & 25.26 & 25.58 & 0.76 & 2.11 & 1.57 & 0.54 & 0.26 & 1 & 2.686 \\
\hline Rastrelliger faughni & 2009 & DGN & 28.92 & 26.25 & 0.44 & 2.3 & 1.07 & 1.23 & 0.54 & 1 & 2.524 \\
\hline Rastrelliger faughni & 2011 & DGN & 23.19 & 22.85 & 0.66 & 2.14 & 1.46 & 0.68 & 0.32 & 1 & 2.55 \\
\hline Rastrelliger faughni & 2011 & PS & 26.49 & 28.12 & 0.81 & 2.5 & 1.61 & 0.89 & 0.36 & 1 & 2.755 \\
\hline Rastrelliger faughni & 2013 & PS & 25.74 & 25.87 & 0.69 & 2.51 & 1.46 & 1.05 & 0.42 & 1 & 2.66 \\
\hline Rastrelliger kanagurta & 2012 & BSGN & 25.34 & 25.49 & 0.87 & 2.72 & 1.71 & 1.01 & 0.37 & 1 & 2.747 \\
\hline Rastrelliger kanagurta & 2013 & BSGN & 26.53 & 25.79 & 0.97 & 4.38 & 1.81 & 2.57 & 0.59 & 1 & 2.834 \\
\hline Rastrelliger kanagurta & 2013 & DGN & 24.7 & 24.69 & 2.3 & 4.8 & 3.25 & 1.55 & 0.32 & 1 & 3.147 \\
\hline Selar crumenophthalmus & 2011 & PS & 28.45 & 27.17 & 0.32 & 1.52 & 0.86 & 0.66 & 0.43 & 1 & 2.413 \\
\hline Decapterus macrosoma & 2011 & PS & 26.69 & 25.94 & 0.55 & 1.84 & 1.25 & 0.59 & 0.32 & 2 & 2.593 \\
\hline Decapterus maraudsi & 2013 & PS & 21.71 & 22.37 & 0.9 & 2.37 & 1.83 & 0.54 & 0.23 & 1 & 2.628 \\
\hline Decapterus tabl & 2012 & PS & 25.14 & 23.82 & 0.73 & 3.21 & 1.53 & 1.68 & 0.52 & 2 & 2.664 \\
\hline Gazza minuta & 2006 & BSGN & 14.8 & 14.77 & 1 & 3.55 & 2.18 & 1.38 & 0.39 & 2 & 2.341 \\
\hline Gazza minuta & 2006 & $\mathrm{LN}$ & 14.03 & 13.3 & 0.82 & 2.16 & 1.94 & 0.22 & 0.1 & 2 & 2.208 \\
\hline Gazza minuta & 2011 & BSGN & 14.03 & 13.9 & 1.2 & 3.87 & 2.49 & 1.38 & 0.36 & 2 & 2.373 \\
\hline Leiognathus equulus & 2007 & BSGN & 16.68 & 17.4 & 1.2 & 4.87 & 2.37 & 2.5 & 0.51 & 2 & 2.524 \\
\hline Leiognathus splendens & 2006 & BSGN & 13.81 & 13.8 & 1.7 & 3.66 & 3.14 & 0.52 & 0.14 & 2 & 2.511 \\
\hline Leiognathus splendens & 2011 & BSGN & 13.52 & 13.02 & 0.81 & 3.1 & 1.94 & 1.16 & 0.37 & 2 & 2.17 \\
\hline Nemipterus bathybius & 2006 & MHL & 24.26 & 23.51 & 0.38 & 1.25 & 1.01 & 0.24 & 0.2 & 2 & 2.35 \\
\hline Nemipterus nemurus & 2008 & MHL & 20.89 & 20.3 & 1.2 & 3.03 & 2.23 & 0.8 & 0.27 & 2 & 2.719 \\
\hline Nemipterus nemurus & 2012 & BSLL & 22.04 & 22.18 & 0.97 & 3.17 & 1.91 & 1.26 & 0.4 & 2 & 2.673 \\
\hline Siganus canaliculatus & 2011 & BSGN & 18.21 & 17.76 & 1.2 & 4.83 & 2.31 & 2.52 & 0.52 & 2 & 2.6 \\
\hline Siganus canaliculatus & 2012 & BSGN & 17.62 & 17.3 & 1.5 & 4.82 & 2.7 & 2.12 & 0.44 & 2 & 2.668 \\
\hline Siganus canaliculatus & 2013 & BSGN & 18.74 & 18.77 & 1.3 & 6.66 & 2.99 & 3.67 & 0.55 & 2 & 2.801 \\
\hline Upeneus sulphureus & 2011 & BSGN & 17.39 & 18.2 & 0.85 & 4.18 & 1.87 & 2.31 & 0.55 & 2 & 2.41 \\
\hline Upeneus sulphureus & 2012 & BSGN & 16.36 & 16.05 & 0.68 & 2.47 & 1.64 & 0.83 & 0.33 & 2 & 2.26 \\
\hline
\end{tabular}

splendens, Nemipterus nemurus, Siganus canaliculatus, and Upeneus sulphureus are fast-growing species (Table $4)$.

Values of growth performance index (Ø), which is a function of $\mathrm{L}_{\infty}$ and $\mathrm{K}$ of the individual species analyzed, are within the range of values reported in other Philippine studies which include that of Decapterus macrosoma (Lavapie-Gonzales et al. 1997; Corpuz et al. 1985; Ingles and Pauly 1984; Silvestre 1986).

Fishing mortality and natural mortality. Estimates of fishing mortality (F) and natural mortality (M) showed that in 2009 Cypselurus naresii and Rastrelliger faughni had $\mathrm{F}$ values greater than $\mathrm{M}$ values which indicate full exploitation/overexploitation of these species during that year. In 2011 Upeneus sulphureus and Siganus canaliculatus had F values greater than M values, and in 2013, Rastrelliger kanagurta and Siganus canaliculatus had $\mathrm{F}$ values greater than $\mathrm{M}$ values.

Exploitation rate. Cypselurus naresii, Rastrelliger faughni, Rastrelliger kanagurta, Decapterus tabl, Siganus canaliculatus and Upeneus sulphureus exhibited an E value exceeding 0.5 , which indicates overexploitation (Figure 31-32).

Recruitment. Recruitment refers to the entry of young batch of fishes to the population. It is important

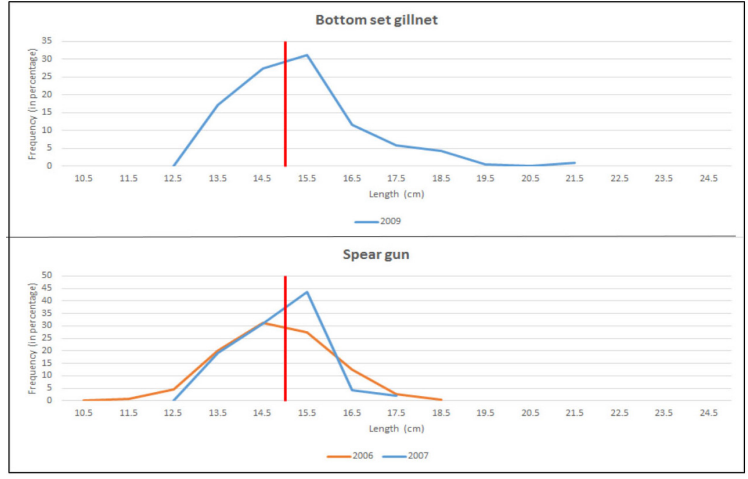

Figure 29. Length frequencies of Siganus fuscescens caught by different types of gear in Tayabas Bay.

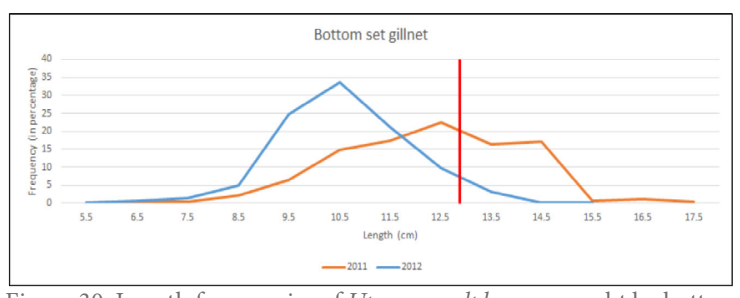

Figure 30. Length frequencies of Upeneus sulphureus caught by bottom set gillnet in Tayabas Bay. 
Table 5. Mean Length and Size at First Maturity of Dominant Species Caught in Tayabas Bay (January 2006-December 2013).

\begin{tabular}{|l|c|c|c|c|}
\hline \multicolumn{1}{|c|}{ Species } & Gear & Year & $\begin{array}{c}\text { Mean Length } \\
(\mathbf{c m})\end{array}$ & $\begin{array}{c}\text { Size at 1st Maturity } \\
(\mathbf{c m})\end{array}$ \\
\hline Sardinella lemuru & BN & 2006 & 14.5 & 14 \\
\hline & LN & 2007 & 16 & 14 \\
\hline Decapterus macrosoma & PS & 2012 & 17 & 15.8 \\
\hline Decapterus tabl & PS & 2012 & 17 & 30 \\
\hline Gazza minuta & PS & 2013 & 19.5 & 12.3 \\
\hline & LN & 2009 & 11.5 & 12.3 \\
\hline Leiognathus equulus & BSGN & 2006 & 11 & 14.9 \\
\hline Leiognathus splendens & BSGN & 2010 & 11.5 & 9.4 \\
\hline Nemipterus bathybius & MHL & 2006 & 10.5 & 17 \\
\hline Nemipterus nemurus & BSLL & 2013 & 17.5 & 16.9 \\
\hline & MHL & 2008 & 17.5 & 16.9 \\
\hline & MHL & 2009 & 20 & 16.7 \\
\hline Rastrelliger faughni & BSGN & 2008 & 22 & 16.7 \\
\hline & DGN & 2009 & 22 & 16.7 \\
\hline & PS & 2011 & 19.5 & 16.7 \\
\hline Rastrelliger kanagurta & BSGN & 2011 & 24 & 16.7 \\
\hline & DGN & 2013 & 22 & 14.7 \\
\hline Sardinella gibbosa & PS & 2012 & 15 & 17.1 \\
\hline Selar crumenophthalmus & PS & 2011 & 18 & 15.1 \\
\hline Siganus canaliculatus & BSGN & 2013 & 14.5 & 15 \\
\hline Siganus fuscescens & BSGN & 2009 & 18.5 & 12.7 \\
\hline & SG & 2007 & 15 & 11.5 \\
\hline Upeneus sulphureus & BSGN & 2011 & & \\
\hline
\end{tabular}

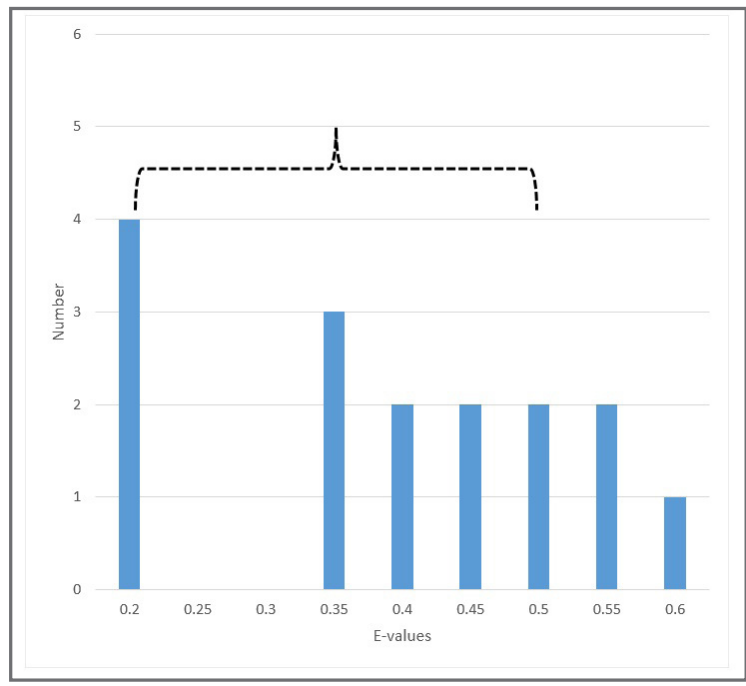

Figure 31. Distribution of exploitation ratio (E) of 16 species analyzed in this study.

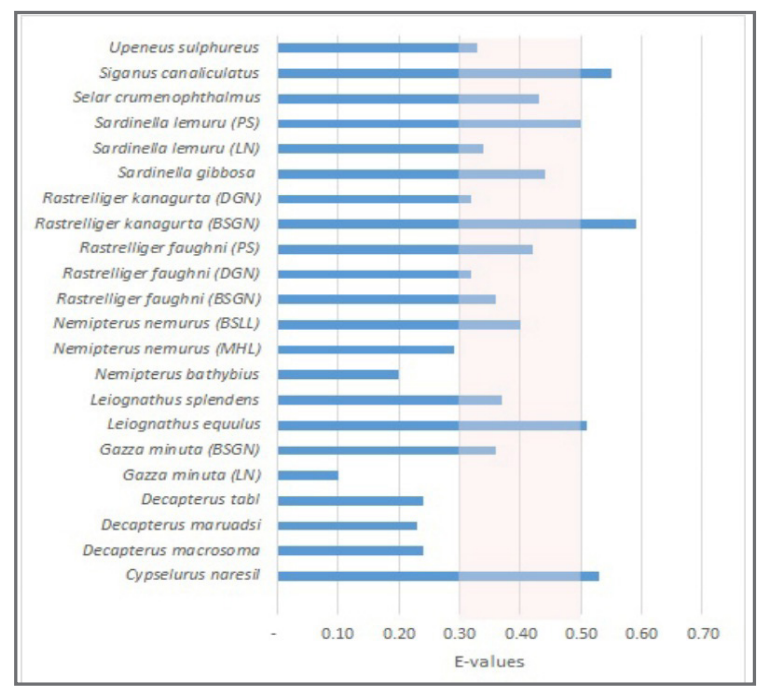

Figure 32. Estimated exploitation ratio (E) of species analyzed in this study.

dominant species. Table 5 shows that 10 of the important fish species caught in Tayabas Bay have a mean size bigger than their length at first maturity. This indicates that these species have at least contributed to the recruitment process of their stocks before these are caught.

\section{SUMMARYANDCONCLUSION}

Based on the results of the 10-year assessment of the fisheries of Tayabas Bay, the number of boats within the bay was 7,197 with 8,580 fishing gears being operated

Mean length and size at first maturity of 
by 10,590 fishermen. The fisherman's density of $34 / \mathrm{km}$ for Tayabas Bay is below the estimate as compared to other major fishing grounds like Lingayen Gulf, Guimaras Strait, and Manila Bay, but slightly higher than the estimates for Honda Bay and Ormoc Bay. The category of Tayabas Bay in 2011 is "moderately fished" area, based on the definition of Fox (20-70 fishers $/ \mathrm{km}$ coastline). The average fisher to banca ratio is 1.47 for small-scale fishing boats, and 15 fishers in commercial vessels.

Fishing gears operated in Tayabas Bay are composed of lines, nets, traps, and hand/gathering instruments. The estimated production is greatly contributed by purse seine (41\%) for commercial gears and bottom gillnet (18\%) for municipal gears. The annual set of data showed that there was an increase of $14.3 \%$ in the number of fishing gear, particularly nets, while lines increased by $15 \%$, traps by $21.7 \%$, and hand instruments by $48.9 \%$. Municipal and commercial fishing is influenced by the occurrence of two pronounced monsoons, that is, southeast monsoon or "habagat" (June to September) which is considered as lean season, and northeast monsoon or "amihan" (October to May). Fisheries activities in the bay are highly increased due to much calmer seas during the latter season which is considered as the peak fishing season in the area.

The trend of catch, effort, and catch per unit effort (CPUE) during the 10-year period showed that an increase in catch could be attained by increasing effort, with fluctuating CPUE. Boat landing observations showed that the highest effort can sustain the maximum production level of $622 \mathrm{MT}$. The abundant species caught at Tayabas Bay are Sardinella lemuru (14\%), Trichiurus lepturus (8\%), Rastrelliger faughni (6\%), Mene maculata (5\%), and Encrasiocholina punctifier (5\%).

In terms of the number of species by family, Carangidae comprises eight percent of the species caught in Tayabas Bay from 2004 to 2013, followed by Serranidae (7\%), Lutjanidae (5\%), Nemipteridae (5\%), and Scaridae (4\%). Catch composition for 10 years was dominated by reef fishes $(70 \%)$, while demersal fishes and pelagic fishes contributed for $15.1 \%$ and $14.8 \%$, respectively. Catches of major gears, such as bottom set gillnet and purse seine, comprise mainly of Carangidae, Scombridae, and Lutjanidae.

As to the sizes and length of fish species caught by different types of gears, nets (such as purse seine and bottom set gillnet) generally catch a higher number of small-sized fishes as compared to other types of gear targeting the same species. The big sizes of fish were caught by drift gillnet and multiple hook and line. The relative abundance of the species per fishing gear showed variation in species composition. For the purse seine, Sardinella lemuru was the most abundant; for bottom gillnet, Leiognathus splendens; for hook and line, Trichiurus lepturus; for liftnet, Encrasicholina punctifer; and for drift gillnet, Sardinella lemuru.

Results of this study showed that Decapterus macrosoma, D. maruadsi, Rastrelliger faughni and Selar crumenopthalmus are slow-growing species, while Sardinella lemuru, Cypselurus naresii, Rastrelliger kanagurta, Gazza minuta, Leiognathus splendens, Nemipterus nemurus, Siganus canaliculatus, and Upeneus sulphureus are fast-growing species.

In 2009 Cypselurus naresii and Rastrelliger faughni had $\mathrm{F}$ values greater than their $\mathrm{M}$ values, which indicates full exploitation/overexploitation of these species during the year. In 2011, Upeneus sulphureus and Siganus canaliculatus had F values greater than $M$ values, while in 2013, Rastrelliger kanagurta and Siganus canaliculatus had $\mathrm{F}$ values greater than $\mathrm{M}$ values.

Cypselurus naresii, Rastrelliger faughni, Rastrelliger kanagurta, Decapterus tabl, Siganus canaliculatus, and Upeneus sulphureus exhibited an E value exceeding 0.5 , which indicates overexploitation of these fish species.

As to recruitment, the nine species analyzed exhibited bimodal recruitment, while seven species showed unimodal recruitment.

A total of 10 of the important fish species caught in Tayabas Bay have a mean size bigger than their length at first maturity, which indicates that these species have at least contributed to the recruitment process of their stocks before these are caught.

\section{R E F E R E N C E S}

Lachica-Aliño. 2001. Results of the Fish Stock Assessment of Honda Bay, Palawan (2000-2001) Resource and Social Assessment of Honda Bay and Puerto Princesa Bay. Fisheries Resource Management Project, Phil.

Aliño PM, Naòola C, Roleda M, and Ticson VS. 2001. Highlights of the assessment of the coastal habitats in Honda Bay, Palawan (2000-2001). Resource and ecological assessment of Honda Bay, Palawan. Vol. II. Chapter 4, Terminal Report. Fisheries Resource Management Project. 11 p.

Aliño PM, Roleda M, Nanola C, Allen GR. 2001. Highlights of the assessment of the coastal habitats in Honda Bay, Palawan (2000-2001).

Armada NB. 1996. The fisheries of San Pedro Bay, Philippines. Final Report on Capture Fisheries Component of the Resource and Ecological Assessment of San Pedro Bay 5: 67p. IMFO Tech. Rep. 16. Institute of Marine Fisheries and Oceanology, College of Fisheries, University of the Philippines in the Visayas (UPV), Miagao, Iloilo.

Asian Development Bank. 2007. Philippines: Fisheries Resource Management Project, 2007 Completion Report of Asian Development Bank. Retrieved from https://www.adb.org/sites/default/files/projectdocument/65541/26616-phi-pcr.pdf

Asian Development Bank. 2008. 2007 Annual report of Asian Development Bank. Retrieved from https:// www.adb.org/sites/default/files/institutional- 
document/31324/annual-report-2007-vol01.pdf

Beverton RJH, Holt SJ. 1956. A review of methods for estimating mortality rates in exploited fish populations, with special references to sources of bias in catch sampling. Rapp. P.-v. Reun. CIEM 140: 67-83.

BFAR. 1977 Fisheries Statistics of the Philippines. Bureau of Fisheries and Aquatic Resources, Manila, Philippines, 1979.

Cinco E, Silvestre G. 1995. Population parameters and exploitation ratios of fishes caught in San Miguel Bay, Philippines. In: Silvestre G, Luna C, Padilla J (editors). Multidisciplinary Assessment of the Fisheries in San Miguel Bay, Philippines (19921993). ICLARM Technical Paper 47. CD-ROM ICLARM, Manila, Philippines.

Corpuz A, Saeger J, Sambilay V. 1985. Population Parameters of Commercially Importamt Fishes in Philippine Waters. Technical Paper, University of the Philippines Visayas, Department of Marine Fisheries (6): 99.

Dalzell P. 1998. Small pelagic fisheries investigation in the Philippines. Part II. The current status. Fishbyte 6(3): 2-4.

Dalzell P, Ganaden RA. 1987. A Review of the Fisheries for Small Pelagic Fishes in Philippines Waters. Tech. Pap. Ser., Bureau of Fisheries and Aquatic Resources (Philipp.). 10(1): 58 p. BFAR, Quezon City, Philippines.

Dalzell P, Peñaflor G. 1989. The fisheries biology of the big-eye scad, Selar crumenopthalmus (Bloch) in the Philippines. Asian Fisheries Science 3: 115-131.

DonaldoSS. 1979. Contributions to the biology of common slipmouths, L. splendens (Cuvier, 1829) caught from Manila Bay. University of the Philippines Diliman, Quezon City. 55p. M. Sc. Thesis.

Dwiponggo AT, Hariati S, Banon M, Palomares L, Pauly D. 1986. Growth, mortality and recruitment of commercially important fishes and penaeid shrimps in Indonesian waters. ICLARM Tech. Pap. 17: 91.

Dy-Ali E. 1998. Growth, mortality, recruitment and exploitation rate of Selar boops in Davao Gulf, Philippines. FAO Fish. Rep. 389: 346-355.

Edralin DRC, Ganaden SR, Fox P. 1988. A comparative study of fish mortality rates in moderately and heavily-fished areas in the Philippines. FAO Fish. Rep. 389: 468-481.

FAO (Food and Agriculture Organization of the United
Nations). 1999. FAO Species Identification Guide for Fishery Purposes. The Living Marine Resources of the Western Central Pacific, Volume 2. FAO, Rome, pp. 764 and 115.

FAO. 1999. FAO Species Identification Guide for Fishery Purposes. The Living Marine Resources of the Western Central Pacific, Volume 3. FAO, Rome, pp. 1698 and 1775.

FAO. 1999. FAO Species Identification Guide for Fishery Purposes. The Living Marine Resources of the Western Central Pacific, Volume 4. FAO, Rome, p. 2659.

FAO. 1999. FAO Species Identification Guide for Fishery Purposes. The Living Marine Resources of the Western Central Pacific, Volume 5. FAO, Rome, pp. 2729, 2839, 3175, 2840, 3004 and 3051.

FAO. 1999. FAO Species Identification Guide for Fishery Purposes. The Living Marine Resources of the Western Central Pacific, Volume 6. FAO, Rome, pp. 3627,3685 and 3721.

Federizon R. 1993. Using Vital Statistics and Survey Catch Composition Data for Tropical Multispecies Fish Stock Assessment: Application to the Demersal Resources of the Central Philippines. Ph. D. Thesis, Alfred-Wegener-Institut fur Polar-and Meeresforchung, Bremerhaven. p. 201.

Fellizar Jr et al. 2001. Socioeconomic and Institutional Assessment of Honda Bay: Research Highlights and Recommendations for Resource Management. Formacion SP, Rongo JM, Sambilay Jr. VC. 1991. Extreme value theory applied to the statistical distribution of the largest lengths of fish. Asian Fisheries Science 4 (1991): 123-135.

Fox Jr Ww. 1970. An exponential surplus-yield model for optimizing exploited fish population. Trans. Am. Fish. Soc. 99: 80-88.

Fox P. 1986. A Manual of Rapid Appraisal Techniques for the Philippines Small Pelagic Fisheries. BFAR, Quezon City. p. 43.

Froese R, Pauly D (editors). 1998. FishBase 4B: Concepts, Designs and Data Devices. ICLARM, Manila, Philippines. p. 293.

Gayanillo Jr FC, Sparre P, Pauly D. 1995. FAO-ICLARM Stock Assessment Tools (FiSAT) User's Manual. FAO Comp. Info. Ser. (Fisheries) 8: 126.

Gayanillo Jr FC, Sparre P, Pauly D. 1996. FAO-ICLARM Stock Assessment Tools. User's Guide, FAO, Rome.

Gomez ED, Alcala AC, San Diego A. 1981. Status of 
Philippine Coral Reefs. Proc. 4th Int. Coral Reef Symp., Manila, Philippines. 1: 275-282.

Guanco MR. 1991. Growth and mortality of Indian mackerel Rastrelliger kanagurta (Scombridae) in the Visayas Sea, Central, Philippines. Fishbyte 9(2): 13-15.

Gulland JA. 1969. Manual of Methods for Fish Stock Assessment. Part 1. Fish Population Analysis. pp. 99-103, 58-74.

Gulland JA. 1983. Fish Stock Assessment: A Manual of Basic Methods. Chishester, U.K., Wiley Interscience, FAO/Wiley series of food and agriculture 1: 223.

Gulland JA. The fish resources of the ocean. Fishing News Books; West Byfleet, UK: 1971.

Hernando A.M. Jr., Flores EEC. 1981. The Philippines squid fishery: a review. Marine Fisheries Review 43(7): 13-20.

Hilborn, R, Walters CJ, 1992. Quantitative fisheries stock assessment: choice, dynamics \& uncertainty. Chapman \& Hall, New York.

Horstmann U. 1975. Some aspects of the mariculture of different siganid species in the Philippines. Philippine Journal Science 12: 5-20.

ICLARM (International Center for Living Aquatic Resources Management). 1996. Resource and Ecological Assessment of Honda Bay, Palawan, Philippines.

Ingles J, Babaran R. 1998. Managing the Fisheries of Guimaras Province, Philippines. Institute of Marine Fisheries and Oceanology, College of Fisheries, University of the Philippines in the Visayas.

Ingles J, Pauly D. 1984. An atlas of the growth, mortality and recruitment of the Philippine fishes. ICLARM Technical Paper 13, 127 p. ICLARM, Manila, Philippines.

Jabat M, Dalzell P. 1998. Preliminary stock assessment of the Davao ring net fishery for bullet tunas and small pelagic fishes in the Camotes Sea, Central Visayas, Philippines. BFAR Technical Paper 11(1): 34.

Lam TJ. 1974. Siganids, their biology and mariculture potential. Aquaculture 3: 325-354.

Lavapie-Gonzales F. 1991. Growth, mortality and recruitment of Decapterus kurroides in Davao Gulf, Philippines. Fishbyte 9(2): 6-9.

Lavapie-Gonzales F, Ganaden SR, Gayanillo Jr FC. 1997. Some Population Parameters of Commercially
Important Fishes in the Philippines. BFAR, Philippines. p. 114.

Loubens G. 1980. Biologie De Quelques Especies De Poisons Du Lagon Neo-Caledonian. III. Croissance. Cah. Indo-Pacific 2: 201-153.

Luistro et al. 1998. Assessment of Honda Bay Fisheries: A Preliminary Report. Unpublished Paper Presented during the National Stock Assessment Program Review held in Iloilo City, November 17-19, 1998.

Manacop PR. 1955. Commercial Trawling in the Philippines. Philippine Journal of Fish. 3(2): 117118

Munro JL, Pauly D. 1983. A simple method for comparing the growth of fishes and invertebrates. ICLARM Fishbyte 1(1): 5-6.

Ordoñez JA, Ginon JS, Maala, A M. 1977. Report on the fishery-oceanographic observations in Tayabas Bay and adjacent waters. Philipp. J. Fish(1): 41-78

Padilla JE. 1991. Managing Tropical Multi-Species Fisheries with Multiple Objectives. Ph. D. Thesis, Simon Fraser University. p. 235.

Palawan Integrated Area Development Project, 1990. Socio-Economic Profile. Puerto Princesa City.

Pauly D. 1978. A Prelimary Compilation of Fish Length Growth Parameters. Ber. Inst. Meereskd. ChristianAlbrechts-Univ. Kiel 55: 1-200.

Pauly D. 1979. Gill Size and Temperature as Governing Factors in Fish Growth: A Generalization of von Bertalanffy's Growth Formula. Berichte des Instituts fur Meereskunde an der Univ. Kiel. No. 63, XV 7, p. 156.

Pauly D. 1980. On the interrelationships between natural mortality, growth parameters, and mean environmental temperature in 175 fish stocks. J. Const. Int. Explor. Mer 39(2): 175-192.

Pauly D. 1984. Fish Population Dynamics in Tropical Waters: A Manual for Use with Programmable Calculators, ICLARM Studies and Reviews 8, p. 325.

Pauly D. 1986. On improving operation and the use of the ELEFAN programs. Part II. Improving the estimation of Loo. ICLARM Fishbyte 4(1): 18-20.

Pauly D, David N. 1981. ELEFAN I: A basic program for the objective extraction of growth parameters from length-frequencies data. Meeresforch 28(4): 205-11.

Pauly D, Munro JL. 1984. Once more on the comparison of growth in fish and invertebrates. Fishbyte 2(1): 21 
Pauly D, Soriano ML. 1986. Some practical extensions to Beverton and Holt's relative yield-per-recruit model, pp. 491.496. In: Maclean JL, Dizon LB, Hosillo LV (editors). The First Asian Fisheries Forum. Asian Fisheries Society, Manila, Philippines.

Penaflor GC. 1988. Growth of L. splendens based on daily otolith rings and length-frequency analysis. Asian Fish. Sci. 2: 83-92.

Perez AG, Anciado PC, Lim J. 2003. A Study on Community Based Law Enforcement in Tayabas Bay. Tanggol Kalikasan sa Timog Katagalugan, Lucena City.

Philbrick C. 1988. Length frequency analysis of pelagic fish species. Fishbyte 6(3): 5-6.

Powell DG. 1979. Estimation of mortality and growth parameters from the length-frequency in the catch. Rapp. P.-V. Reun. CIEM 175: 167-169.

Puerto Princesa City Socio-economic Profile. 1998.

Ramos MH, Candelario MB, Mendoza EM, Gonzales FL. 1999. The Honda Bay Fisheries: An Assessment. Unpublished Paper Presented during the National Stock Assessment Program Review held in Tuguegarao, Cagayan, December 6-11, 1999.

Roleda M, Alcantara L, Ticson VS, Montaño B. 2001. Spatial and temporal variation in the macrophyte community structure of Honda Bay, Puerto Princesa City, Palawan. Resource and ecological assessment of Honda Bay, Palawan. Vol. II. Chapter 6, Terminal Report. Fisheries Resource Management Project. p. 23.

Sambilay Jr VC. 1991. Depth-distribution Patterns of Demersal Fishes of the Samar Sea, Philippines, and their Use for Estimation of Mortality. M.S Thesis. University of the Phil. in the Visayas. p. 66.

Schaefer MB. 1954. Some aspects of the dynamics of populations important to the management of the commercial marine fisheries. Inter-Am. Trop. Tuna Comm., Bull. 1(2): 27-56.

Schroeder RE. 1977. Preliminary results of the sizematurity survey of commercially important fishes of Honda Bay. The Philippine Journal of Fisheries 15(2): 127-173.

Schroeder RE. 1980. Philippine Shore Fishes of the Western Sulu Sea.

Schroeder RE. 1982. Length-weight relationship of fishes from Honda Bay, Palawan, Philippines. Fish. Res. J. Philipp 7(2): 50-53.
Silvestre G, Soriano M, Pauly D. 1991. Sigmoid selection and the Beverton and Holt yield equation. Asian Fish. Sci. 4: 85-98.

Silvestre GT, Pauly D. 1987. Estimate of yield and economic rent from Philippine demersal stocks (1946 - 84) using vessel housepower as an index of fishing effort. University of Philippine in the Visayas. Fish. J. 3(1-2) : 11-24.

Silvestre GT. 1986. Preliminary analysis of the growth, mortality and yield-per-recruit of ten trawl-caught fish species from the Philippines. Univ. Phil. Coll. Fish., Dept. Mar. Fish. Tech. Rep. 7: 1-41.

Sparre P, Venema SC. 1992. Introduction to Tropical Fish Stock Assessment. Part I. Manual. FAO Fish Tech. Pap. No. 306.1, rev. 1. Rome, FAO. p. 376.

Tandog-Edralin D, Ganaden SR, Fox P. 1988. A comparative study of fish mortality rates in moderately and heavily fished areas of the Philippines, pp. 468-481. In: Venema SC, Christensen JM, Pauly D (editors), Contribution to Tropical Fisheries Biology. FAO/ DANIDA Follow-up Training Course on Fish Stock Assessment in the Tropics. Denmark, 1986 and Philippines 1987. FAO Report (389).

Tiews K, Caces-Borja P. 1959. On the availability of fish of the Family Leiognathidae Lacepede in Manila Bay and San Miguel Bay and on their accessibility to controversial fishing gears. Philipp. J. Fish. 7(1): 59-85.

Tsuda RT, Bryan PG, Fitsgerald WJ, Tobias WJ. 1974. Juvenile-adult rearing of Siganus (Pisces: Siganidae) in Guam. South Pacific Commission Seventh Technical Meeting on Fisheries, Nuku'alofa, Tonga, July 15-19, 1974. p. 6.

Villoso EP, Hermosa G. 1982. Sex ratio and sexual maturity of some fishes caught by otter trawl in Samar Sea, Philippines. Fish. Res. J. Phil. 7(1):18-30

Warfel E, Manacop PR. 1950. Otter trawl explorations in Philippine waters. Research Report 25, Fish and Wildlife Service, U.S. Dept. Int., Washington, D.C.

Weber W, Jothy AA. 1977. Observation on the fish Nemipterus spp. (Family Nemipteridae). Malaysia (1972). Arch. FischWiss. 28: 109-122.

Wetherall JA. 1986. A new method for estimating growth and mortality parameters from length-frequency data. ICLARM Fishbyte 4(1): 12-14.

Zamora P. 1980. Philippine Mangroves: Assessment of Status; Environmental Problems: Conservation and Management Strategies, University of the Philippines. 